\title{
Baiu near Japan and Its Relation to Summer Monsoons over Southeast Asia
}

\section{and the Western North Pacific}

\author{
By Ryuichi Kawamura ${ }^{1}$ \\ National Research Institute for Earth Science and Disaster Prevention, Tsukuba, Ibaraki, Japan
}

and

Takio Murakami

Department of Meteorology, School of Ocean and Earth Science and Technology, University of Hawaii, Honolulu, USA

(Manuscript received 11 September 1997, in revised form 20 May 1998)

\begin{abstract}
The slowly evolving annual cycle (signified as "L-mode") was defined by the sum of the first three sinusoids in a series of climatological pentad mean data of infrared equivalent black body temperature, $850 \mathrm{hPa}$ wind, temperature, geopotential height and specific humidity, while the rapidly varying annual cycle (denoted by "S-mode") was determined by adding up the remaining sinusoids.

During early summer, the L-mode exhibited a blocking-type configuration with a ridge over the Kamchatka-Okhotsk region, whereas a trough stretched eastward from northern China (center of a continental heat low) to Japan and beyond. The establishment of a locally independent L-mode anticyclonic cell over the Sea of Okhotsk enhanced low-level easterly anomalies from the vicinity of the Aleutian islands through northern Japan. The L-mode easterly anomalies merged with southwesterly anomalies along the southeastern periphery of a continental-scale heat low, thus generating a pronounced cyclonic shear zone around Japan accompanied by low-level moisture convergence. This L-mode lower tropospheric trough in intrinsically association with the east-west temperature gradient between East Asia and the western North Pacific plays a vital role in the formation of Baiu system in early summer.

The L-mode southwesterlies along the east coast of China, which are attributed to the prominence of the continental-scale heat low, served as a bridge that links the monsoon westerlies of tropical origin with the westerly jet of mid-latitude origin. This resulted in producing a low-level westerly duct extending from the South China Sea to the central North Pacific. At the Baiu onset phase (mid-June), the S-mode onset cyclone of convective origin developed over the South China Sea, and concurrently the S-mode onset anticyclone organized to the northeast of the onset cyclone. The consolidated effect of these onset vortexes amplified in the vicinity of the low-level westerly duct was to cause the northward advection of warm and moist air from the tropics to southern Japan.

By mid-July, the Asian continental heat low reached its peak and the summer monsoon over Southeast Asia became fully established. At the Baiu withdrawal phase (late July), the continental heat low began to decay because of land surface cooling; nevertheless, the L-mode Pacific High still developed northward and was most intense at the beginning of August. As the east-west temperature gradient between the ocean and continent decreased, the L-mode lower tropospheric trough near Japan dissipated, whereas L-mode WNPM (summer monsoon over the western North Pacific) trough prevailed in the subtropics. The withdrawal of Baiu was also characterized by the dominance of S-mode disturbances as well as the Baiu onset.
\end{abstract}

1 Corresponding author: Ryuichi Kawamura, National Research Institute for Earth Science and Disaster Prevention, 3-1 Tennodai, Tsukuba, Ibaraki 305-0006, Japan. E-mail: kawamura@ess.bosai.go.jp (C) 1998, Meteorological Society of Japan 
It is thus anticipated that the seasonal evolution of L-mode circulation field, associated with continentocean thermal contrast, strongly regulates the activities of S-mode perturbations in and around the lowlevel westerly duct. It seems likely that the westerly duct served as a wave guide for the barotropic Rossby wave dispersion of the S-mode disturbances. The presence of horizontally sheared L-mode flow may also contribute substantially to the development and persistence of S-mode vortexes via in situ barotropic interaction process between the two modes. At any rate, the combined contribution of the L-mode flow and S-mode disturbances is to make such local climatological events as the onset and withdrawal of Baiu so rapid and dramatic.

\section{Introduction}

It has long been known that Baiu (in Japanese) or Meiyu (in Chinese) is of midlatitude frontal character combined with tropical convective nature. Ninomiya and Murakami (1987) had access to most literature pertaining to Baiu published before the mid-1980s, while Tao and Chen (1987) surveyed research activities on Meiyu during the same period. The Baiu onset around early June coincides nearly with the onset of summer monsoon over the northern Bay of Bengal (Murakami, 1958). Flohn and Oeckel (1956) were the first to note that large amounts of moisture are transported by the prevailing low-level southwesterlies, from the Bay of Bengal through southern China to Japan and beyond. Ninomiya (1978, 1980), Kato (1989), and Kodama (1993) have all indicated results similar to those of Flohn and Oeckel (1956). Hence, a strong association of Baiu with the Southeast Asian monsoon (signified as "SEAM"; see Appendix) is implied.

In the meantime, Murakami (1959), Saito (1966), Kurashima (1968), and Asakura (1971) have all confirmed that the equatorial western North Pacific is also an important moisture source region. As the Baiu advances from its early to later stage, the moisture transport due to the southeasterly trade flowing around the Pacific high becomes increasingly important. Recently, Murakami and Matsumoto (1994), and Wang and $\mathrm{Xu}$ (1997) claimed a near simultaneous occurrence of the Baiu onset with the monsoon onset over the tropical western North Pacific (denoted as "WNPM"). Nakazawa (1992) and Tanaka (1992) pointed out that the seasonal phase lock of intraseasonal oscillation can be seen in the Asian summer monsoon system, and that such phase-locked convective activities in the tropics significantly affect the Baiu onset and withdrawal. Subsequently, Ueda et al. (1995) postulated a possible association of the Baiu withdrawal with enhanced large-scale convection in the WNPM domain. These studies are strong evidence for a climatological linkage between Baiu and WNPM.

The transient (not climatological) character of Baiu has also attracted the attention of many investigators. Ninomiya and Muraki (1986) mentioned that intraseasonal variations seen in the activity of Baiu is intimately related to active convection over the South China Sea. Nitta (1987), Huang and Li (1987), and Kurihara and Tsuyuki (1987) demonstrated occurrence of a summertime extratropical wave train in association with anomalous convection around the Philippines. Kawamura et al. (1996) showed that during boreal summer, midlatitude intraseasonal oscillation (ISO), which displays a barotropic wave train structure along a great circle traversing the North Pacific, emerges as a part of the Rossby wave dispersion out of the equatorial convective forcing and influences upon the transient aspects of Baiu in individual years.

Despite the efforts of many theoretical as well as synoptic meteorologists cited here, the questions of why Baiu commences on the specific calendar time of the year, and also how and why Baiu is related to SEAM and/or WNPM, have not been answered satisfactorily. The present study is a sequel to the Kawamura et al.'s (1996) paper, but pays special attention to the climatological aspects of Baiu. As is well known, Baiu occurs during an early part of the summer and, as such, its timescale is shorter than the season (90 days or less). It is then possible to categorize Baiu as an intraseasonal climatological event. In comparison, the SEAM and WNPM monsoons can be regarded as an interseasonal climatological event since they both last longer than four to five months. Without doubt, the monsoons are of thermal origin regulated by the annual cycle of the sun (i.e., annual and/or semi-annual cycles). Many of meteorological variables over the monsoon domain exhibit winter-summer asymmetry in intensity as well as in phase. Such winter-summer asymmetric annual cycle can be approximated, with sufficient accuracy, by the sum of the first (1 year), second $(1 / 2$ year) and third ( $1 / 3$ year) harmonics. Due to this reason, in the present study we define the Lmode by consolidating the first three sinusoids. The remaining sinusoids describe the rapidly evolving intraseasonal climatological variability and are denoted as the "S-mode." Included in the S-mode variability are Baiu, and the onset/withdrawal of SEAM and WNPM, whose timescales are of course shorter than the season. The space scale also turns out to be different; namely, the L-mode is of planetary-scale while the S-mode is of synoptic-scale. We anticipate that the S-mode is responsible for bringing about rapid and localized climate over the Asian continentwestern North Pacific domain. How the L- and Smodes jointly contribute to the life cycle of Baiu, SEAM and WNPM will be detailed in Sections 3 
and 4. Section 5 documents the counterclockwise progression of L-mode during boreal summer. A concluding summary of the results and discussion are found in Section 6 .

\section{Data and analysis procedures}

Datasets used in the present study include: (1) infrared equivalent blackbody temperature $\left(T_{B B}\right)$ with a spatial resolution of $1^{\circ} \times 1^{\circ}$ obtained by the Japanese Geostationary Meteorological Satellite for the period of 1985-93, and (2) $u, v, T, z$ and $q$ extracted from the ECMWF (European Centre for Medium-Range Weather Forecasts) routine analysis with a spatial resolution of $2.5^{\circ} \times 2.5^{\circ}$ for the period of 1985-93. The ECMWF data assimilation system remained practically unchanged during this period, thus providing datasets of nearly uniform quality.

The climatological daily mean value is first computed by averaging over the entire 9-year period. Owing to the relatively short sample size, the climatological daily mean value thus evaluated is subjected to some statistical noises caused by day-today synoptic events occurring in individual years. To eliminate such undesirable noises, a low-pass time filter is then applied to a series of climatological data (signified as $A_{i}$ ) as follows:

$$
\bar{A}_{i}=\sum_{k=-5}^{+5} w_{k} A_{i-k}, \quad i=1 \text { to } 365 .
$$

Here, $A$ represents any of variables $\left(T_{B B}, u, v, T\right.$, $z$ and $q$ ). In Eq. (1), $A_{i}$ is assumed to be cyclic at $i=1$ and 365 , and the weights $w_{k}$, are the same as those used by Kawamura et al. (1996). The response is approximately 0.2 for a 10 -day period and zero for noises with periods of less than 8 days. To further eliminate unnecessary noises, we compute a (1-2-1) weighted mean of three consecutive $\bar{A}_{i}$ data. These smoothed pentad mean data at every other pentad are hereafter designated as " $\langle A\rangle_{i}$ ", $i=1,73$. Hence, $\langle A\rangle$ describes the climatological annual cycle, which is identical from year to year.

As the next step, we performed a harmonic analysis to the time series of $\langle A\rangle$ as follows:

$$
\langle A\rangle=A(0)+A(l)+A(s),
$$

where $A(0)$ is the climatological annual mean; $A(l)$ represents the sum of the first three harmonics, whereas $A(s)$ denotes the sum of remaining sinusoids. Hence, $A(l)$ defines a slowly evolving annual cycle with periods longer than 120 days. $A(s)$ indicates a rapidly varying annual cycle with periods shorter than 90 days. Murakami and Matsumoto (1994) determined the normal onset (withdrawal) date of Baiu at $35^{\circ} \mathrm{N}, 135^{\circ} \mathrm{E}$ to be around Pentad 31 (40), which means that Baiu lasts only for about 45 days. By contrast, the time-scale of both SEAM and WNPM is much longer and exceeds 120 days (see
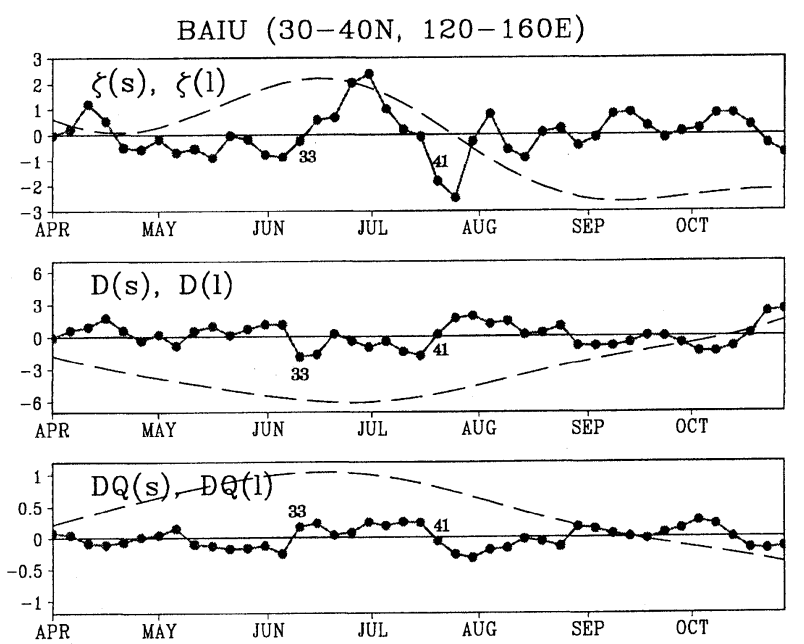

Fig. 1. Time series of $850 \mathrm{hPa}$ relative vorticity $\zeta$ (unit is $10^{-6} \mathrm{~s}^{-1}$ ), divergence $D$ (unit is $10^{-7} \mathrm{~s}^{-1}$ ) and moisture flux convergence $D Q$ (unit is $10^{-5} \mathrm{~g} \mathrm{~kg}^{-1} \mathrm{~s}^{-1}$ ) averaged over the BAIU domain $\left(30^{\circ}-40^{\circ} \mathrm{N}, 120^{\circ}-160^{\circ} \mathrm{E}\right)$. L- and S-modes are denoted by dashed and full lines, respectively. Note that the starting pentad is Pentad 19 (April 1-5). Also shown are the onset phase (Pentad 33) and withdrawal phase (Pentad 41).

their Fig. 2). Both $A(l)$ and $A(s)$ are equally important when describing the evolution of monsoons (including Baiu).

Figure 1 shows the time series of $850 \mathrm{hPa}$ relative vorticity $\zeta(l)$, divergence $D(l)$ and moisture flux convergence $D Q(l)$ (dashed lines), averaged over the Baiu domain $\left(30^{\circ}-40^{\circ} \mathrm{N}, 120^{\circ}-160^{\circ} \mathrm{E}\right)$. Also shown are the time series of $\zeta(s), D(s)$ and $D Q(s)$ (full lines) at $850 \mathrm{hPa}$ over the same domain. $\langle D Q\rangle$ indicates the net convergence of climatological pentad mean moisture flux $[\langle q u\rangle,\langle q v\rangle]$ as follows:

$$
\langle D Q\rangle=-\iint_{M}\left(\frac{\partial\langle q u\rangle}{a \cos \varphi \partial \lambda}+\frac{\partial\langle q v\rangle \cos \varphi}{a \cos \varphi \partial \varphi}\right) d M,
$$

where $M$ represents the Baiu domain. Hence, note that $[\langle q u\rangle,\langle q v\rangle]$ is not identical to $[\langle q\rangle\langle u\rangle,\langle q\rangle\langle v\rangle]$. As in Eq. (2), $\langle D Q\rangle$ is then partitioned into three components as

$$
\langle D Q\rangle=D Q(0)+D Q(l)+D Q(s) \text {. }
$$

Both $D Q(l)$ and $D Q(s)$ exhibit a distinct seasonal character. By definition, $D Q(l)$ and $D Q(s)$ in Fig. 1 are plotted as the departure (anomaly) from the annual mean. For brevity, the term "anomaly" will rarely be used when referring either to L- or S-mode variables. Likewise, the term " $850 \mathrm{hPa}$ " is hereafter omitted because most of figures are for the $850 \mathrm{hPa}$ level. This level is most suited for representing the low-level monsoon flow. 

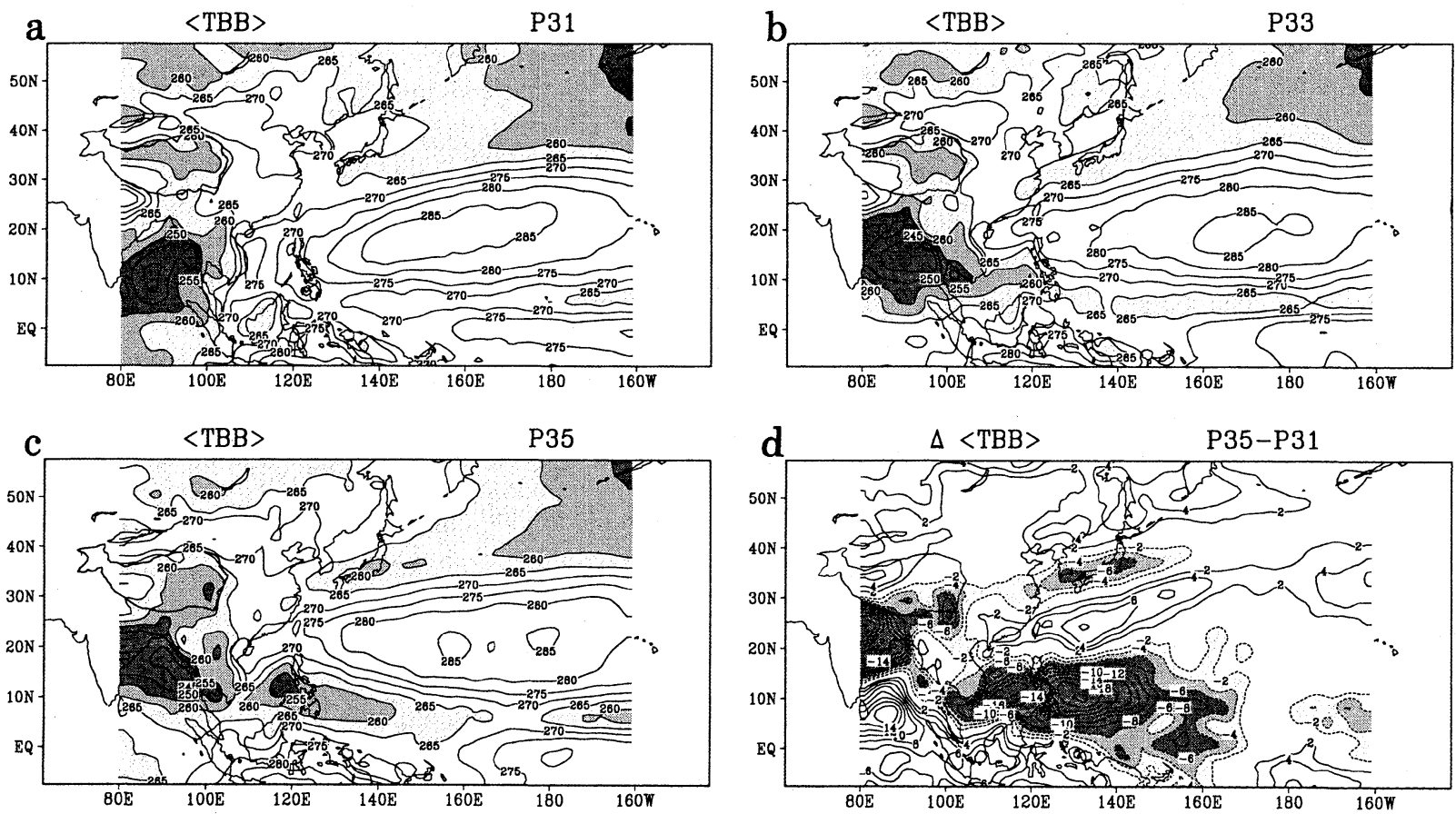

Fig. 2. (a) Climatological pentad mean $\left\langle T_{B B}\right\rangle$ at Pentad 31 (May 31-June 6). Contour interval is 5 $\mathrm{K}$, and shading indicates regions of less than $265 \mathrm{~K}$. (b) As in (a) but for Pentad 33 (June 10-14). (c) As in (a) but for Pentad 35 (June 20-24). (d) Difference in $\left\langle T_{B B}\right\rangle$ between Pentad 31 and 35. Contour interval is $2 \mathrm{~K}$, and shading indicates negative values.

Between late April (Pentad 24) and late July (Pentad 42 ), $\zeta(l)$ is positive (cyclonic) with its peak around mid-June (Pentad 34), mid-June is also the time of minimum $D(l)$ (convergence) and maximum $D Q(l)$ (moisture sink). These are favorable conditions for the Baiu to begin around Pentad 34. An actual onset date can be determined from an inspection of the time series of $\zeta(s), D(s)$ and $D Q(s)$. For instance, the onset can be defined as the first pentad when $\zeta(s)$ becomes positive, while the withdrawal is determined by the last pentad before $\zeta(s)$ returns to negative. Following this definition, the onset (withdrawal) pentad is Pentad 33 (41). Our definition is consistent with previous studies (e.g., Tanaka, 1992; Murakami and Matsumoto, 1994, Wang and $\mathrm{Xu}, 1997$ ). Actually, the onset (withdrawal) date slightly differs when different variables used. In the time series of $D(s)$, the onset is characterized by a step-like shift from divergent to convergent at Pentad 32 to 33, while the withdrawal occurring as a step-like shift from convergent to divergent at Pentad 40 to 41 . Since $D Q(s)$ is nearly out of phase with $D(s)$, the onset (withdrawal) date as defined by $D Q(s)$ is identical to that determined from $D(s)$. The onset (withdrawal) date is not only sensitive to a variable used, but also varies significantly from one part to another in and around the Baiu domain. In this study, we have defined the onset (withdrawal) pentad of Baiu from an all-inclusive synoptic inspec- tion of the pentad mean maps for $\left\langle T_{B B}\right\rangle, T_{B B}(l)$ and $T_{B B}(s)$, as will be elaborated in the following sections.

\section{Baiu onset}

\subsection{Synoptic aspects}

How and when the Baiu begins over Japan can be clearly seen in Figs. 2a to 2c, which show the pentad mean $\left\langle T_{B B}\right\rangle$ from Pentad 31 (May 31-June 4) to Pentad 35 (June 20-24). At Pentad 31, an illorganized band of $\left\langle T_{B B}\right\rangle$ less than $265 \mathrm{~K}$ stretches off the southern coast of Japan. This cloud band becomes more clearly established as it shifts northward and reaches Japan by Pentad 33. Between Pentad 33 and 35, the cloud band further intensifies as indicated by decrease in $\left\langle T_{B B}\right\rangle$ down to below $260 \mathrm{~K}$. Hence, Pentad 33 (June 10-14) can be defined as the onset pentad of Baiu in Japan. South of the Baiu cloud band is the Pacific dry zone with $\left\langle T_{B B}\right\rangle$ greater than $265 \mathrm{~K}$. In association with the northward migration of the Pacific dry zone, early summer rains near Taiwan terminate before Pentad 33 .

The intertropical convergence zone (ITCZ) stretches along about $5^{\circ}-10^{\circ} \mathrm{N}$ across the equatorial Pacific. In the vicinity of the Philippines, which lie at the western end of ITCZ, $\left\langle T_{B B}\right\rangle$ sharply decreases from Pentad 33 to 35 . This implies the onset of WNPM sometime between Pentad 33 and 35, i.e., 

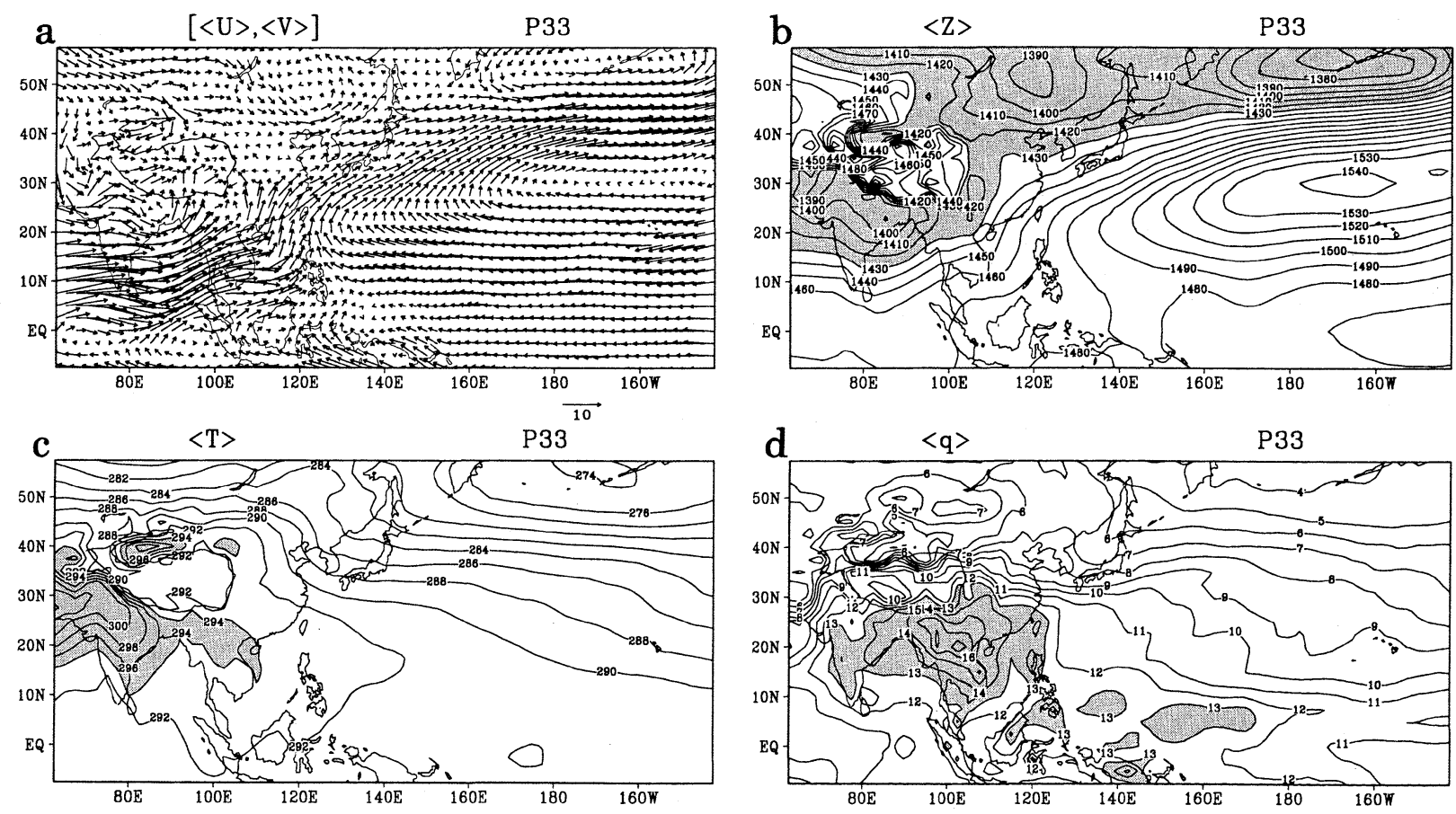

Fig. 3. (a) Climatological pentad mean $850 \mathrm{hPa}$ wind at Pentad 33 (onset). Unit is $10 \mathrm{~m} \mathrm{~s}^{-1}$. (b) As in (a) but for $850 \mathrm{hPa}$ geopotential height. Contour interval is $10 \mathrm{~m}$, and shading indicates regions of less than $1430 \mathrm{~m}$. (c) As in (a) but for $850 \mathrm{hPa}$ temperature. Contour interval is $2 \mathrm{~K}$, and shading denotes regions of greater than $294 \mathrm{~K}$. (d) As in (a) but for $850 \mathrm{hPa}$ specific humidity. Contour interval is $1 \mathrm{~g} \mathrm{~kg}^{-1}$, and shading indicates regions of greater than $13 \mathrm{~g} \mathrm{~kg}^{-1}$.

nearly concurrent with or slightly behind the Baiu onset. Further to the west over the Bay of Bengal is intense convection of SEAM, which commences as early as Pentad 27 (not shown). SEAM tends to extend northward as well as westward, hence causing the monsoon onset over southern India at Pentad 33 .

The relative magnitude of the Baiu onset as compared to the WNPM and/or SEAM onset can be measured by the difference in $\left\langle T_{B B}\right\rangle$ between Pentad 31 and 35 , this difference being signified as $\Delta\left\langle T_{B B}\right\rangle$ in Fig. 2d. There are three separate negative $\Delta\left\langle T_{B B}\right\rangle$ zones of intense convection. First, the minimum $\Delta\left\langle T_{B B}\right\rangle$ center of less than $-20 \mathrm{~K}$ over central India reflects the monsoon onset there. Second, the onset of WNPM clearly stands out as a marked negative $\Delta\left\langle T_{B B}\right\rangle$ zone over the tropical western Pacific with a minimum of below $-20 \mathrm{~K}$. Third, the commencement of Baiu is characterized by a WSW-ENE oriented band of weakly negative $\Delta\left\langle T_{B B}\right\rangle$ of -4 to $-6 \mathrm{~K}$ from central China to Japan. The Baiu onset is thus much less pronounced than the WNPM/SEAM onset in terms of $\Delta\left\langle T_{B B}\right\rangle$ magnitude. It should be noted, however, that the Baiu onset is an important and unique climatological event near Japan.

Figure 3 shows the major circulation systems at Pentad 33, which may directly or indirectly influence the Baiu onset. To begin with, the Baiu system is accompanied by a prominent meridional gradient in both $\langle T\rangle$ and $\langle q\rangle$ across Japan, indicating the frontal character of Baiu. $\langle T\rangle$ is highest over Iran and Pakistan, while $\langle q\rangle$ is largest over northern Indo-China. Thus, the equivalent potential temperature reaches its maximum between about $20^{\circ}$ and $30^{\circ} \mathrm{N}$, with a distinct north-south gradient over the equatorial Arabian Sea and the Bay of Bengal. There exists a remarkable meridional gradient in $\langle z\rangle$ over the Arabian Sea and the Bay of Bengal. These key SEAM areas are dominated by monsoon westerlies in excess of $10 \mathrm{~m} \mathrm{~s}^{-1}$. After reaching the South China Sea, the monsoon westerlies turn cyclonically and shift toward southern China and Japan as southwesterlies. These southwesterlies correspond to what is generally referred to as the low-level jet (Tao and Chen, 1987). A dominant heat low is centered over Mongolia at around $50^{\circ} \mathrm{N}, 115^{\circ} \mathrm{E}$ (Fig. $3 \mathrm{~b}$ ).

The Aleutian Low is a permanent feature through the year, although substantially weakening from winter to summer. Equatorward of the Aleutian Low is the Pacific High, which moves northward and intensifies as winter advances to summer. The trade winds prevailing to the south of the Pacific High merge with the SEAM westerlies near the Philippines. This confluence zone, which was previously located over the South China Sea prior to Pentad 

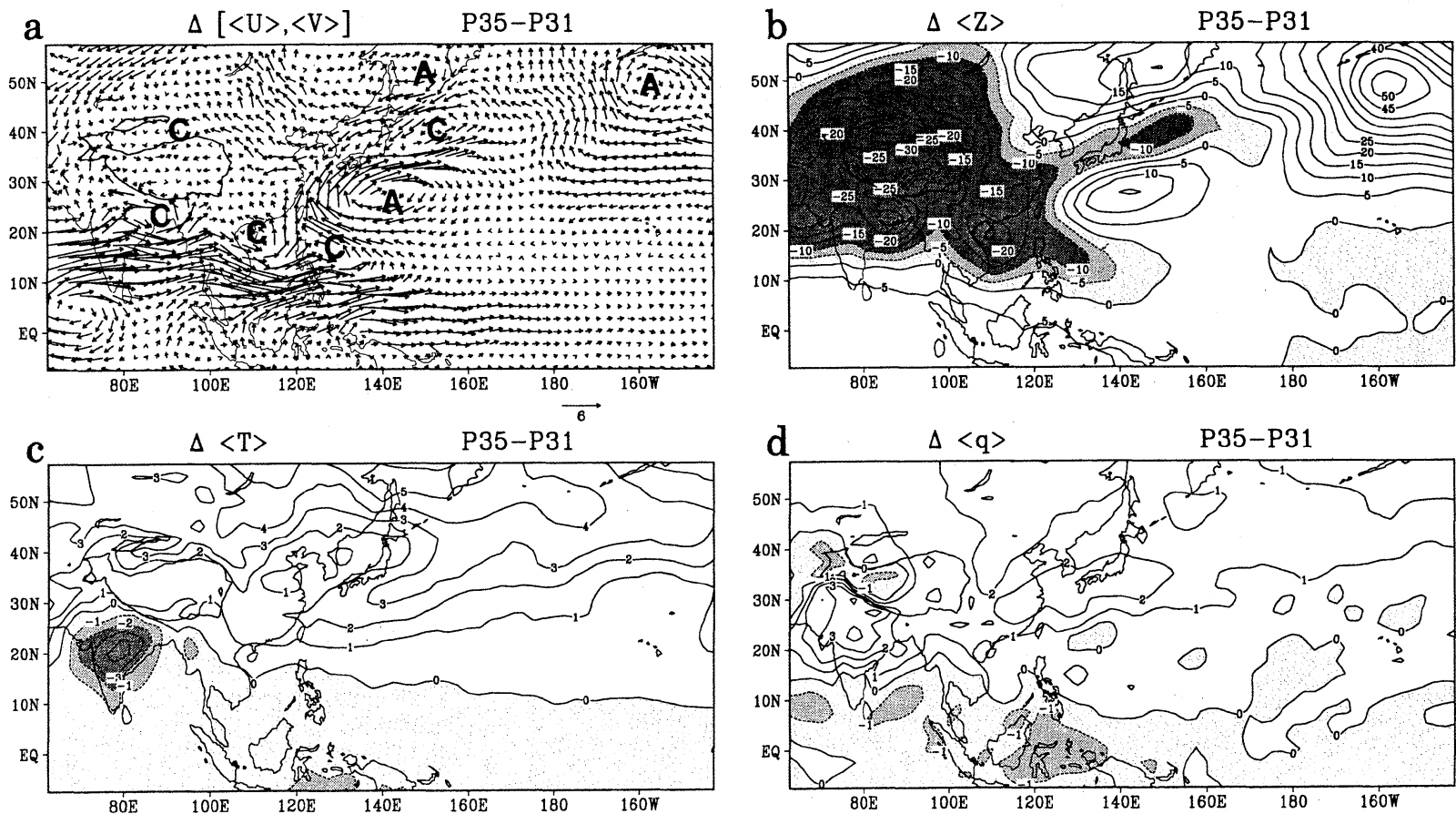

Fig. 4. (a) Difference in climatological pentad mean $850 \mathrm{hPa}$ wind between Pentad 31 and 35 . Unit is $6 \mathrm{~m} \mathrm{~s}^{-1}$. The letters $C$ and $A$ denote cyclonic and anticyclonic circulation anomalies, respectively. (b) As in (a) but for $850 \mathrm{hPa}$ geopotential height. Contour interval is $5 \mathrm{~m}$, and shading indicates negative values. (c) As in (a) but for $850 \mathrm{hPa}$ temperature. Contour interval is $1 \mathrm{~K}$, and shading denotes negative values. (d) As in (a) but for $850 \mathrm{hPa}$ specific humidity. Contour interval is $1 \mathrm{~g} \mathrm{~kg}^{-1}$, and shading indicates negative values.

30, gradually shifts eastward into the western Pacific around $140^{\circ}-160^{\circ} \mathrm{E}$, where WNPM becomes fully established by Pentad 46 (August 14-18).

Which of the circulation systems mentioned here is closely linked to the Baiu onset? This question can be answered by examining Figs. 4a to $4 \mathrm{~d}$, which show the differences in $[\langle u\rangle,\langle v\rangle],\langle z\rangle,\langle T\rangle$ and $\langle q\rangle$, respectively, between Pentad 31 and 35 . An immediate indication is that the Baiu onset is part of planetary-scale circulation changes occurring not only over the Asian continent but also over the western Pacific. Note that the symbols " $A$ " and " $C$ " denote anticyclonic and cyclonic circulation changes, respectively. Except for the near-equatorial regions, $\Delta[\langle u\rangle,\langle v\rangle]$ is in approximate geostrophic balance with $\Delta\langle z\rangle$. Of particular interest is the presence of a pronounced " $C$ " circulation cell centered in between the Altai Mountains and the Tibetan Plateau, where dry weather persists. The " $C$ " cell in question may correspond to a heat low. On the other side of the Tibetan Plateau is a train of three " $C$ " cells at $\left(25^{\circ} \mathrm{N}, 85^{\circ} \mathrm{E}\right),\left(20^{\circ} \mathrm{N}, 110^{\circ} \mathrm{E}\right)$, and $\left(16^{\circ} \mathrm{N}, 130^{\circ} \mathrm{E}\right)$, respectively. These " $C$ " cells are embedded within the convectively activated SEAM and WNPM domain (see Fig. 2d) and, thus, they are of convective origin. When these four " $C$ " cells are combined together, they tend to form a continental-scale cy- clonic circulation encircling the whole Asian continent (Fig. 4a) with monsoon westerlies equatorward of the convection-induced three " $C$ " cells and extratropical southeasterlies (northeasterlies) to the east (west) of the continental cloud-free " $C$ " cell.

In Fig. 4a, note the presence of a wave train structure with two cyclonic " $C$ " cells and two anticyclonic " $A$ " cells aligned along the longitudes $120^{\circ}-140^{\circ} \mathrm{E}$ from $10^{\circ} \mathrm{N}$ to $50^{\circ} \mathrm{N}$. Whether this wave train really indicates the Rossby-wave dispersion emanating out of the convection-induced " $C$ " cell is not yet known. However, it is more important that this wave train contributes, to a great extent, to the Baiu onset. In particular, a distinct cyclonic " $C$ " cell near Japan indicates the development of Baiu. This " $C$ " cell is sandwiched between two anticyclonic " $A$ " cells, one at $25^{\circ} \mathrm{N}, 140^{\circ} \mathrm{E}$ and the other at $50^{\circ} \mathrm{N}, 145^{\circ} \mathrm{E}$. Poleward (equatorward) of the Baiu front are northeasterly (southwesterly) winds that carry cold (warm) air from the Okhotsk Sea (the tropical western $\mathrm{Pa}$ cific), as suggested in Figs. 3c and 4a. This results in a prominent meridional $\Delta\langle T\rangle$ gradient across Japan (Fig. 4c), which stands in sharp contrast with a rapid dissipation of meridional temperature gradient over northern China (Kato, 1985; 1987). It is interesting, likewise, that $\Delta\langle T\rangle$ is positive but very small in the vicinity of the Sea of Japan. As seen in 

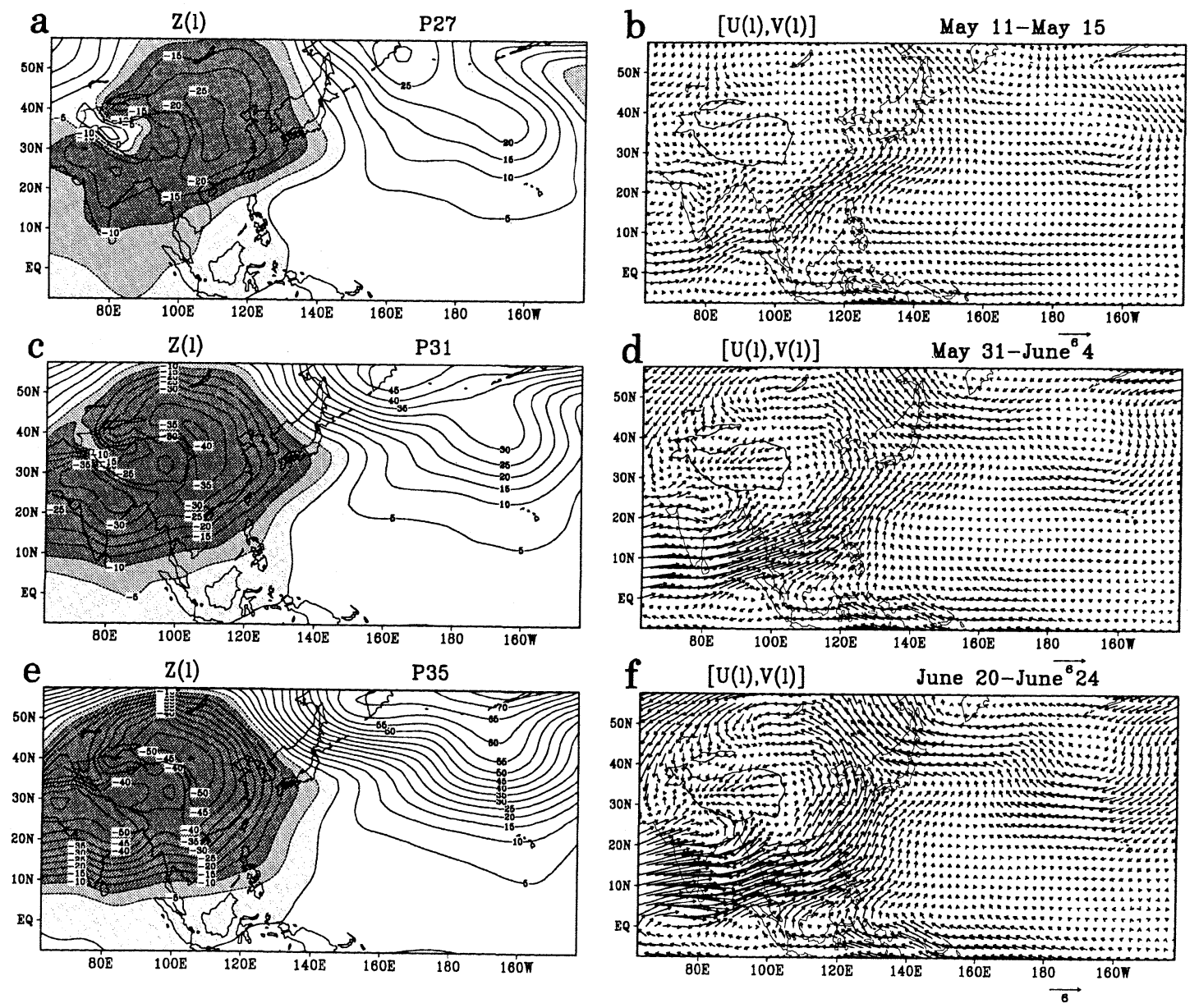

Fig. 5. Spatial patterns of $850 \mathrm{hPa}$ geoptential height $z(l)$ at Pentad 27 (a), Pentad 31 (c) and Pentad 35 (e). Contour interval is $5 \mathrm{~m}$, and shading indicates negative values. Spatial patterns of $850 \mathrm{hPa}$ wind $[u(l), v(l)]$ at Pentad $27(\mathrm{~b})$, Pentad $31(\mathrm{~d})$ and Pentad $35(\mathrm{f})$. Unit is $6 \mathrm{~m} \mathrm{~s}^{-1}$.

Fig. 4 d, a moist $\Delta\langle q\rangle$ tongue also favors Baiu activities.

Yet another feature of interest in Fig. $4 \mathrm{c}$ is a distinct negative $\Delta\langle T\rangle$ cell over central India, where the monsoon rains just begin. It is well known among Indian meteorologists that the temperature quickly falls after the commencement of monsoon rains. Likewise, one should not overlook the dominance of an anticyclonic " $A$ " cell over the northeastern Pacific (Fig. 4b), which stands in sharp contrast to the continental " $C$ " cell.

\subsection{Contribution of L-mode to the Baiu onset}

As emphasized earlier, the Baiu onset is associated with a rapid intensification of the heat low over the Asian continent. This can be more firmly substantiated by taking a look at Fig. 5. At Pentad 27 (May 11-15), $z(l)$ is lowest to the leeward of the Tibetan Plateau. At the southeastern periphery of the heat low are prominent southwesterly $[u(l), v(l)]$ winds in intimate association with an ocean-to-continent $z(l)$ gradient. These southwesterlies over southern China are expected to be strongest at around $850 \mathrm{hPa}$ because of the presence of a continent-to-ocean $T(l)$ gradient at and below that level (figure not shown). Namely, they correspond to the so-called low-level jet at $850 \mathrm{hPa}$ (Tao and Chen, 1987). The low-level jet was initially formed around Pentad 20 (early April) due to warming up of the surface $T(l)$ over Indo-China (Tian and Yasunari, 1998). This is followed by a rapid increase in the surface $T(l)$ in the Mongolia-eastern Siberia region, facilitating the birth of the continental heat low slightly after Pentad 23. By Pentad 35 (Fig. 5e), the heat low becomes fully established and dominates almost all of East Asia. Circling around the periphery of the heat low are the continental-scale cyclonic flows; namely, westerlies (easterlies) along the southern (northern) periphery, and southerlies (northerlies) along the eastern (western) periphery. By contrast, during the winter half, East Asia is dominated by a continental-scale anticyclonic circulation with northerly cold outbreaks emanating out of the Siberian High and the easterly trade winds sweeping over the Bay of Bengal and Arabian Sea 

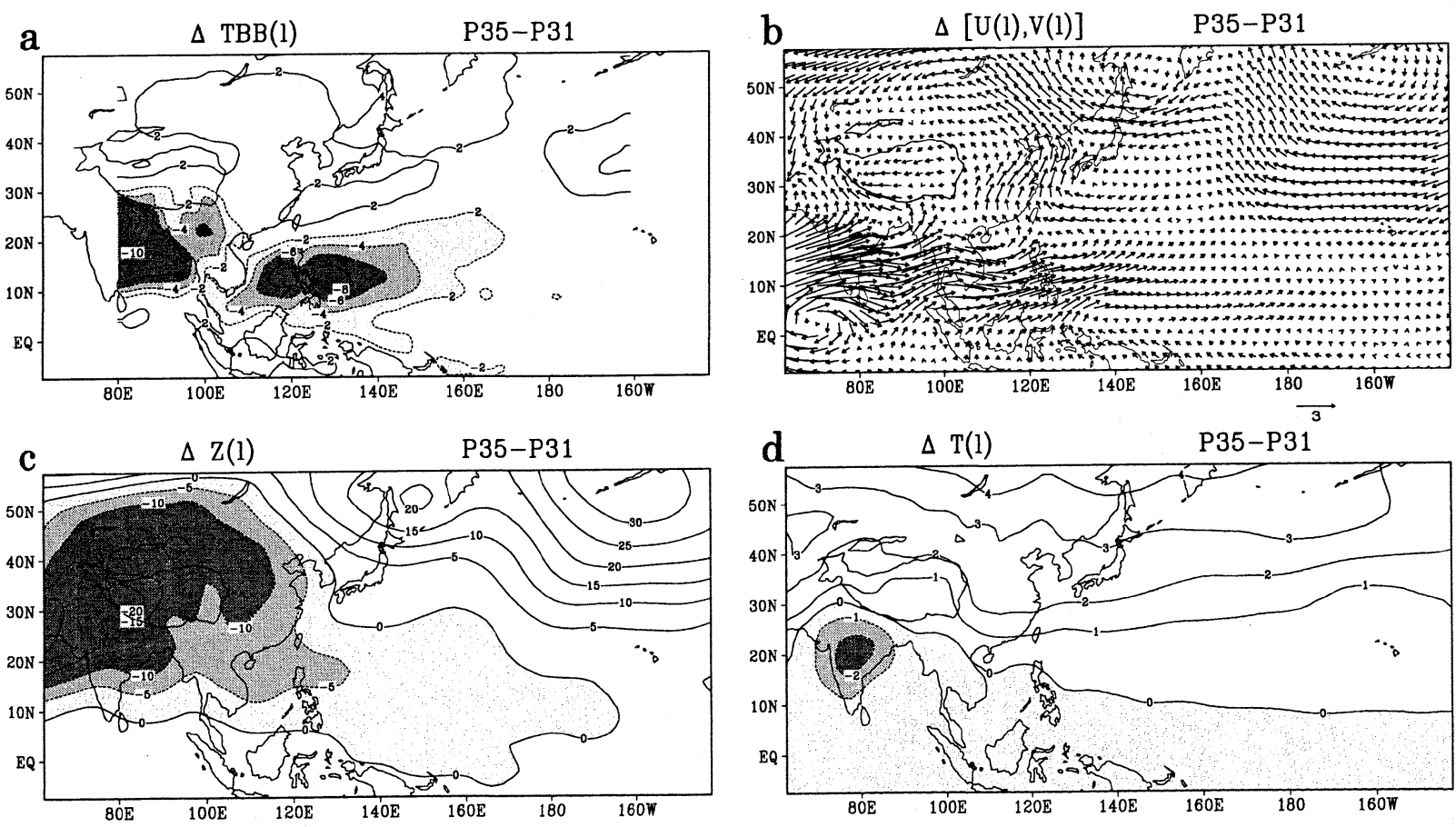

Fig. 6. (a) Difference in $T_{B B}(l)$ between Pentad 31 and 35. Contour interval is $2 \mathrm{~K}$, and shading denotes negative values. (b) As in (a) but for $850 \mathrm{hPa}$ wind $[u(l), v(l)]$. Unit is $3 \mathrm{~m} \mathrm{~s}^{-1}$. (c) As in (a) but for $850 \mathrm{hPa}$ geopotential height $z(l)$. Contour interval is $5 \mathrm{~m}$, and shading indicates negative values. (d) As in (a) but for $850 \mathrm{hPa}$ temperature $T(l)$. Contour interval is $1 \mathrm{~K}$, and shading indicates negative values.

(figure not presented).

Let us now turn our attention to what is occurring over the extratropical western Pacific. In contrast with the Asian continent, $z(l)$ is positive and anticyclonic, reflecting the seasonal weakening of the Aleutian Low, the seasonal northward migration of the Pacific High, and the enhancement of a local anticyclonic cell in the vicinity of the Sea of Okhotsk, which is customarily termed as the "Okhotsk High" by Japanese meteorologists (e.g., Kato, 1995). The prevailing $[u(l), v(l)]$ wind there is easterly to southeasterly (Fig. 5, right). Of interest is the southeasterly $[u(l), v(l)]$ wind poleward of Japan, which progressively intensifies from Pentad 27 to 35 due to the increase in the continent-ocean thermal contrast. The southeasterly $[u(l), v(l)]$ wind of extratropical Pacific origin merges with the southwesterly $[u(l), v(l)]$ wind of tropical monsoon origin, so that an east-west oriented L-mode trough is formed in the vicinity of Japan. As indicated in Fig. 1, this L-mode trough is initiated around mid-April, gradually intensifies, and reaches its peak by mid-June.

Differences in $T_{B B}(l),[u(l), v(l)], z(l)$ and $T(l)$ between Pentad 35 and 31, as shown in Figs. 6a to $6 \mathrm{~d}$, are direct manifestations of the degree to which the L-mode contributes to the Baiu onset. These Figures should be compared with Figs. 2d, 4a, 4b and $4 \mathrm{c}$, which are for differences in the original pen- tad mean $\left\langle T_{B B}\right\rangle,[\langle u\rangle,\langle v\rangle],\langle z\rangle$ and $\langle T\rangle$, respectively. First, a comparison between Fig. 6a and Fig. 2d reveals that the L-mode contributes little to the onset of Baiu, since $\Delta T_{B B}(l)$ is not negative but positive near Japan. Around $13^{\circ} \mathrm{N}, 130^{\circ} \mathrm{E}, \Delta T_{B B}(l)$ amounts to $-8 \mathrm{~K}$, which accounts for about $50 \%$ of large negative $\Delta\left\langle T_{B B}\right\rangle$ in that vicinity. $\Delta T_{B B}(l)$ over central India amounts to $-14 \mathrm{~K}$ or less, being about $70 \%$ of $\Delta\left\langle T_{B B}\right\rangle$. This implies that $\Delta T_{B B}(l)$ component is more dominant over the Indian subcontinent. The role of L-mode becomes less important as one approaches the western Pacific. In the vicinity of Japan, no distinctive indications of the Baiu frontal structure in the $\Delta T(l)$ field are seen in Fig. 6d. However, evidence will be presented later that the L-mode plays an important role during the onset phase of Baiu.

Of particular interest in Fig. $6 \mathrm{c}$ is that $\Delta z(l)$ exhibits a distinct ocean-continent contrast in extratropical regions poleward of about $25^{\circ} \mathrm{N}$. In comparison, $\Delta T(l)$ in Fig. $6 \mathrm{~d}$ increases monotonically with increasing latitude without any apparent oceancontinent contrast. This puzzling problem can be explained by taking a look at the $\Delta T(l)$ field at $1000 \mathrm{hPa}$ level (figure not shown). As expected, the $1000 \mathrm{hPa} \Delta T(l)$ is two to three times as high over the Asian continent as that over the western Pacific. The higher surface temperature favors 


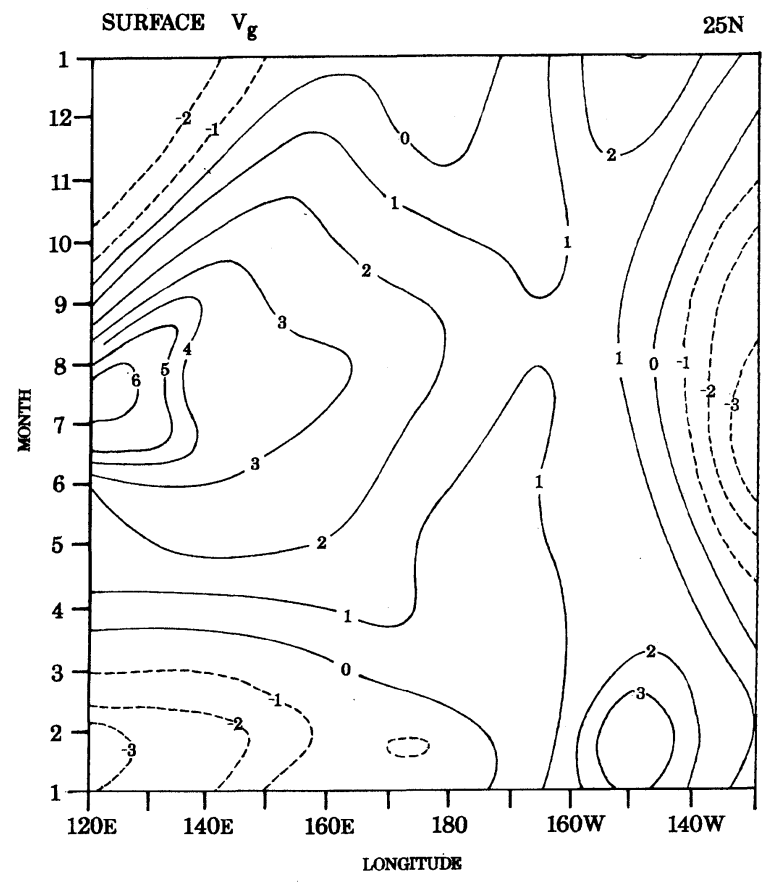

Fig. 7. Time-longitude section of geostrophic meridional wind at $25^{\circ} \mathrm{N}$, estimated at surface level. Contour interval is $1 \mathrm{~m} \mathrm{~s}^{-1}$, and dashed lines denote northerly wind.

the development of the heat low over the Asian continent, thus resulting in significant continentocean contrast in $\Delta z(l)$. Over the East China Sea $\left(25^{\circ}-35^{\circ} \mathrm{N}, 120^{\circ}-130^{\circ} \mathrm{E}\right)$, an east-west $\Delta z(l)$ gradient and the southerly $\Delta v(l)$ flow are approximately in geostrophic balance (see Fig. 6b and 6c).

The geostrophic meridional wind $v_{g}$ evolves quite regularly with season, as illustrated in Fig. 7, which shows the longitude-month section of $v_{g}$ along $25^{\circ} \mathrm{N}$ computed from the climatological monthly mean surface pressure prepared by Sadler et al. (1987). The Siberian High is a governing pressure system in boreal winter with northerly $v_{g}$ penetrating deep into the Pacific. Conversely, the continental heat low is a dominant pressure system in boreal summer, with southerly $v_{g}$ all the way from $120^{\circ} \mathrm{E}$ to $180^{\circ}$. Thus, the western North Pacific clearly stands out as one of the important monsoon domains, since the alternation of $v_{g}$ from northerly in winter to southerly in summer satisfies the monsoon criterion introduced by Khromov (1957). April is the month of alternation from northerly to southerly $v_{g}$. Between $120^{\circ}$ and $140^{\circ} \mathrm{E}$, the southerly $v_{g}$ sharply increases during early June, which coincides with the Baiu onset phase. The Baiu terminates when the southerly $v_{g}$ becomes strongest, exceeding $6 \mathrm{~m} \mathrm{~s}^{-1}$ near $120^{\circ}-130^{\circ} \mathrm{E}$ in mid-July. During August, a marked zone of strong $v_{g}$ tends to expand eastward to around $140^{\circ} \mathrm{E}$ where WNPM is at its peak phase.
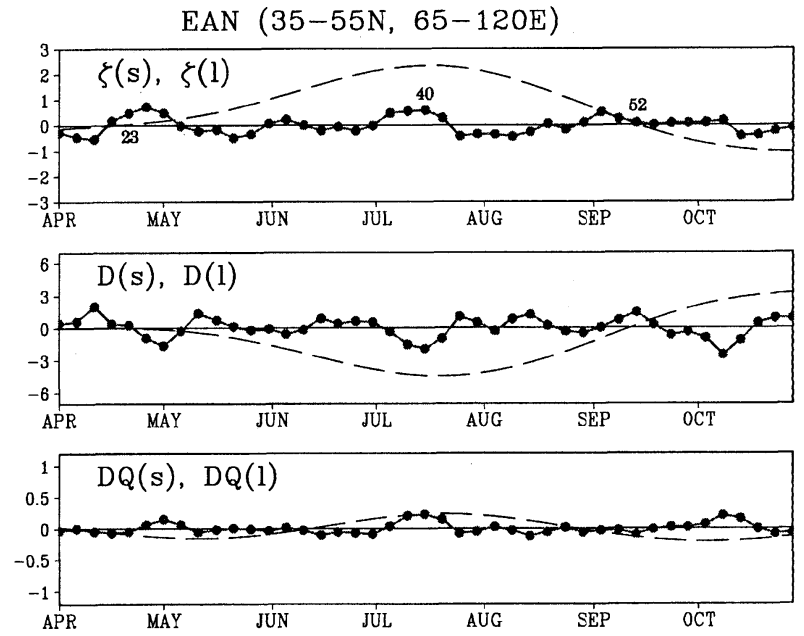

Fig. 8. Time series of lower tropospheric relative vorticity $\zeta$ (unit is $10^{-6} \mathrm{~s}^{-1}$ ), divergence $D$ (unit is $10^{-7} \mathrm{~s}^{-1}$ ) and moisture flux convergence $D Q$ (unit is $10^{-5} \mathrm{~g} \mathrm{~kg}^{-1} \mathrm{~s}^{-1}$ ) averaged over the northern half of East Asia $\left(35^{\circ}-55^{\circ} \mathrm{N}\right.$, $\left.65^{\circ}-120^{\circ} \mathrm{E}\right) . \mathrm{L}-$ and S-modes are denoted by dashed and full lines, respectively.

These features support that the continental heat low, which is accompanied by southerlies along its eastern periphery, has an influential effect on the life cycle of Baiu as well as WNPM (e.g., Kato, 1989; Kodama, 1993). Incidentally, SEAM also becomes fully established in mid-July when the southerly $v_{g}$ becomes most pronounced in terms of monsoonal winds. Such coincidence is not fortuitous but suggests that SEAM is also regulated, in some way, by the continental heat low.

An exact life cycle of the continental heat low is demonstrated by the dashed line in the top panel of Fig. 8, which shows the evolution of $\zeta(l)$ averaged over the northern half of East Asia $\left(35^{\circ}-55^{\circ} \mathrm{N}, 65^{\circ}-\right.$ $\left.120^{\circ} \mathrm{E}\right)$. The area-averaged $\zeta(l)$ varies very slowly with season and becomes cyclonic for about five months from mid-April to mid-September with its maximum in mid-July. We consider that the Lmode vorticity $\zeta(l)$ is a direct manifestation of the continental heat low that evolves with the seasonal migration of the sun. By contrast, the S-mode vorticity $\zeta(s)$, as shown by the full line in Fig. 8 (top), exhibits frequent shifts between cyclonic and anticyclonic, and hence contributes little to the seasonal dependence of the continental heat low.

\subsection{Contribution of $S$-mode to the Baiu onset}

Our primary objective with this subsection is to detail the structural features of S-mode and, if possible, to clarify how the S-mode contributes to the Baiu onset. To facilitate further investigation, we computed differences in various S-mode variables between Pentad 31 (pre-onset) and Pentad 35 (post- 

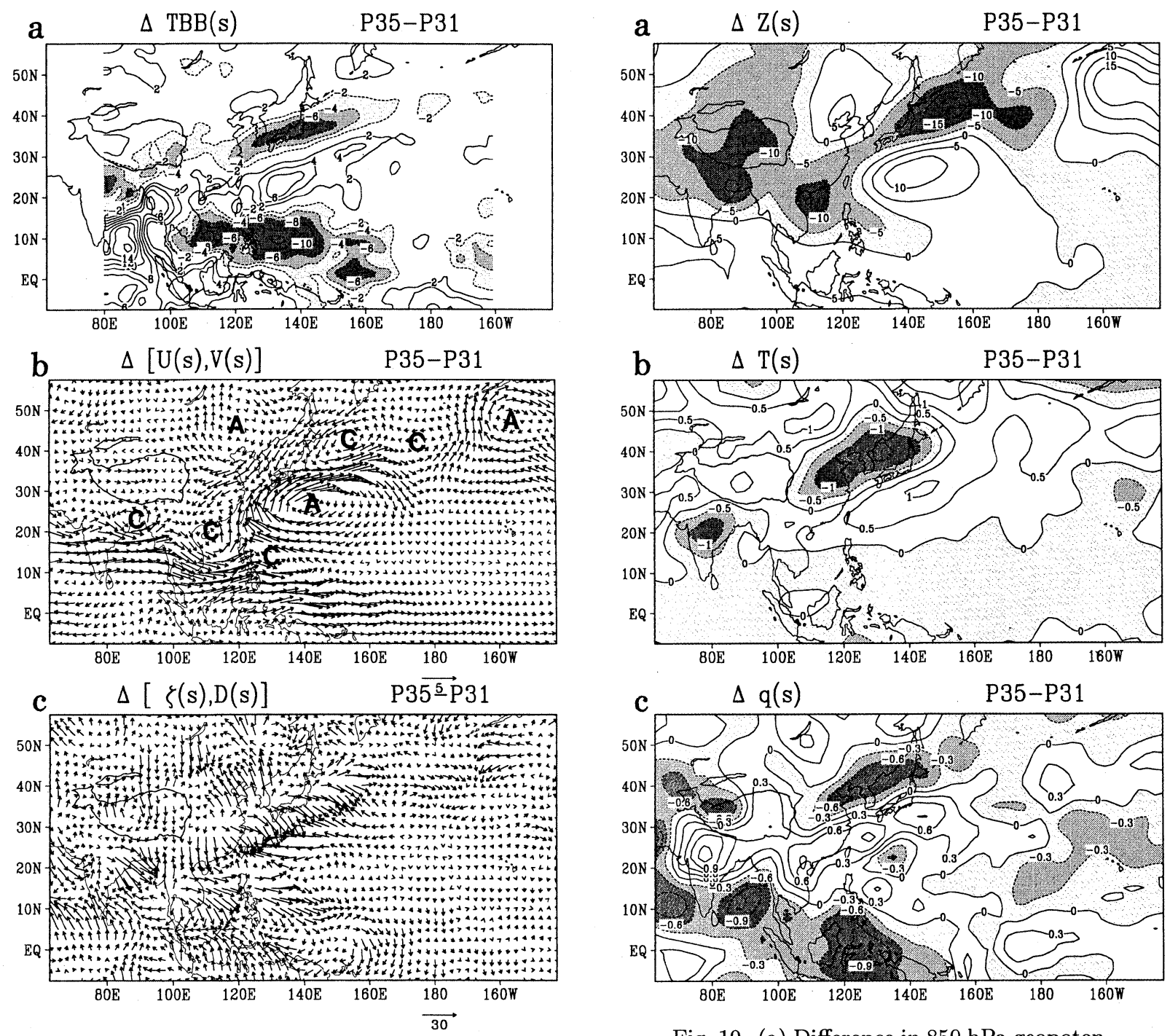

Fig. 9. (a) Difference in $T_{B B}(s)$ between Pentad 31 and 35 . Contour interval is $2 \mathrm{~K}$, and shading denotes negative values. (b) As in (a) but for $850 \mathrm{hPa}$ wind $[u(s), v(s)]$. Unit is $5 \mathrm{~m} \mathrm{~s}^{-1}$. The letters $C$ and $A$ denote cyclonic and anticyclonic circulation cells. (c) As in (a) but for $850 \mathrm{hPa}$ relative vorticity $\zeta(s)$, divergence $D(s)$. Note that $\Delta \zeta(s)$ and $\Delta D(s)$ are plotted in a vector form with cyclonic (anticyclonic) $\Delta \zeta(s)$ pointing eastward (westward) and divergent (convergent) $\Delta D(s)$ directed northward (southward). Units are $1.5 \times 10^{-5}$ $\mathrm{s}^{-1}$ and $3 \times 10^{-6} \mathrm{~s}^{-1}$ for $\Delta \zeta(s)$ and $\Delta D(s)$, respectively.

onset), as shown in Figs. 9 and 10. Note that $\Delta \zeta(s)$ and $\Delta D(s)$ in Fig. 9c are plotted in a vector form with cyclonic (anticyclonic) $\Delta \zeta(s)$ pointing eastward (westward) and divergent (convergent) $\Delta D(s)$ directed northward (southward).

The Baiu onset over and around Japan can be clearly seen in Fig. 9a, with $\Delta T_{B B}(s)$ as low as $-6 \mathrm{~K}$

Fig. 10. (a) Difference in $850 \mathrm{hPa}$ geopotential height $z(s)$ between Pentad 31 and 35. Contour interval is $5 \mathrm{~m}$, and shading denotes negative values. (b) As in (a) but for $850 \mathrm{hPa}$ temperature $T(s)$. Contour interval is $0.5 \mathrm{~K}$. (c) As in (a) but for $850 \mathrm{hPa}$ specific humidity $q(s)$. Contour interval is $0.3 \mathrm{~g} \mathrm{~kg}^{-1}$.

or less. An immediate indication is a dominant role of S-mode on enhancement of convective rains during the Baiu onset phase. One of the important roles of S-mode is to establish a distinct S-mode trough extending northeastward from southern China, via the East China Sea, to northern Japan and beyond (see Figs. 9b and 10a). As a matter of course, the newly established S-mode trough is associated with prominent cyclonic $\zeta(s)$ and convergent $D(s)$ in Fig. 9 c. Another aspect of S-mode is its capability to produce a front-type structure in the temperature and moisture fields around Japan. As suggested in Figs. $9 \mathrm{~b}$ and $3 \mathrm{c}$, the southwesterly $[\Delta u(s), \Delta v(s)]$ flow equatorward of the S-mode trough causes the northward advection of warm and moist air from the trop- 

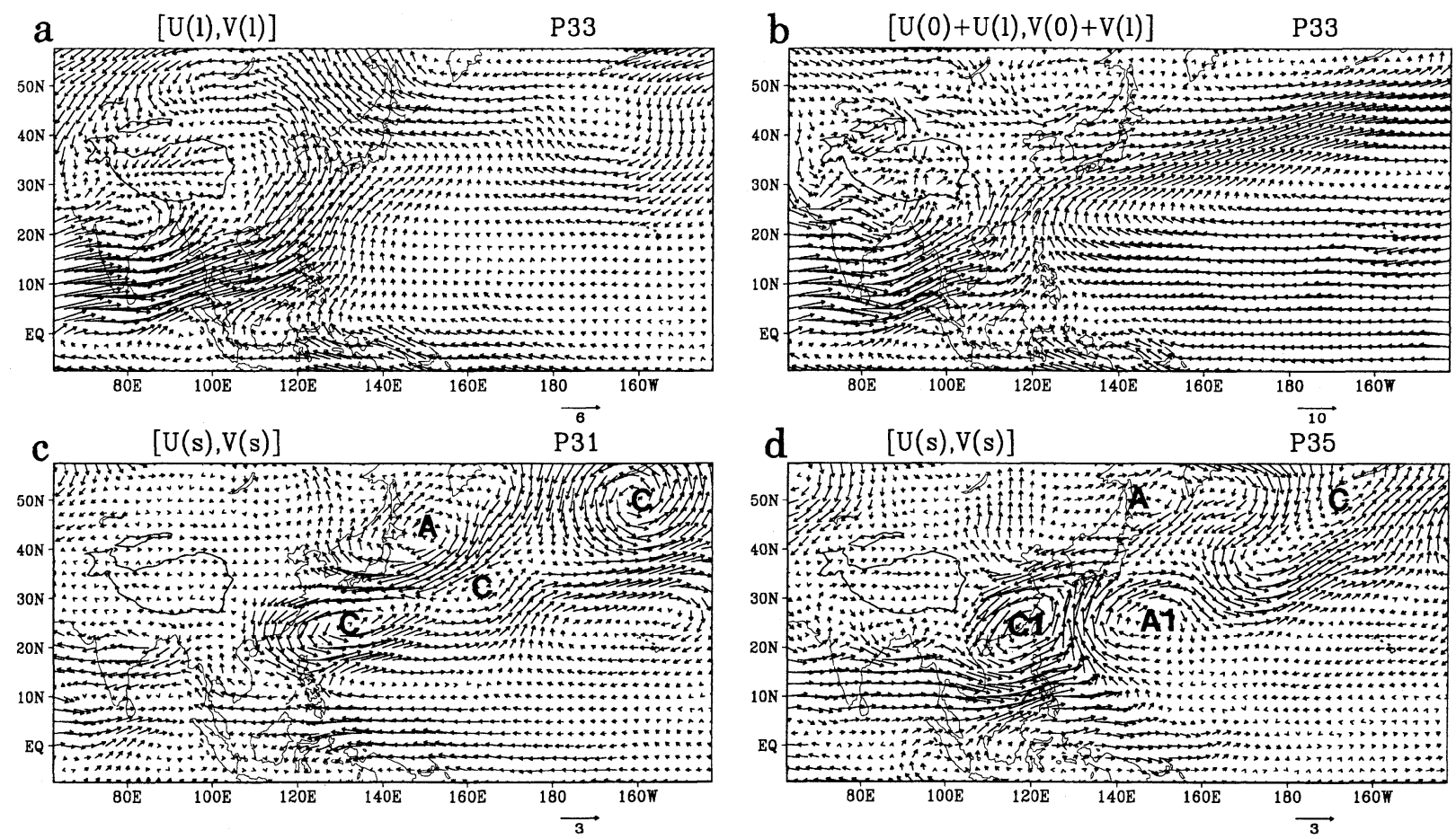

Fig. 11. (a) Spatial pattern of $850 \mathrm{hPa}$ wind $[u(l), v(l)]$ at Pentad 33. Unit is $6 \mathrm{~m} \mathrm{~s}^{-1}$. (b) As in (a) but for basic flow $[u(0)+u(l), v(0)+v(l)]$, which means the sum of the L-mode flow and the annual mean flow. Unit is $10 \mathrm{~m} \mathrm{~s}^{-1}$. (c) Spatial pattern of $850 \mathrm{hPa}$ wind $[u(s), v(s)]$ at Pentad 31 . Unit is 3 $\mathrm{m} \mathrm{s}^{-1}$. The letters $C$ and $A$ denote S-mode cyclonic and anticyclonic circulation cells, respectively. (d) As in (c) but for Pentad 35.

ical Pacific to southern Japan, whereas the northeasterly counterpart poleward of the trough carries cold and dry air from the Sea of Okhotsk to northern Japan, resulting in a strong meridional gradient in both $\Delta T(s)$ and $\Delta q(s)$ across Japan (Figs. 10b and 10c). It is also seen that Meiyu is established around eastern China. We should note here that the intensification of the Okhotsk High is less clear at the onset phase of Baiu in terms of S-mode activity. This feature is in contrast with the L-mode Okhotsk High enhanced at the same phase (see Fig. 6c).

The S-mode is also an important contributor to the onset of WNPM. In the vicinity of the Philippines, the magnitude of $\Delta T_{B B}(s)$ is greater than $12 \mathrm{~K}$ (sign omitted), which is about twice as large as that near Japan. The $[\Delta u(s), \Delta v(s)]$ pattern in Fig. 9b displays a wave train structure encompassing not only the SEAM, WNPM and Baiu domains, but also the higher latitude regions of the North $\mathrm{Pa}$ cific. Obviously, the S-mode activity is insignificant over a majority of the Asian continent, including the Indian subcontinent. Fig. 9b also shows that the S-mode activities in the tropical central Pacific eastward of the dateline between the equator and $30^{\circ} \mathrm{N}$ are relatively quiet.

\subsection{Combined contribution of $L$ - and $S$-modes to the Baiu onset}

The L-mode is primarily responsible for initiating the Asian continental heat low before the Baiu onset. By Pentad 33 (Fig. 11a), the Asian heat low becomes appreciably strong and associated $[u(l), v(l)]$ flows display a prominent cyclonic (anticyclonic) shear inside (outside) of the heat low. To define the basic flow, we add the L-mode flow to the annual mean flow. The consolidated basic flow, i.e., $[u(0)+u(l), v(0)+v(l)]$, at Pentad 33 is shown in Fig. 11b. The consolidated winds are southwesterly along the east coast of China, while they are westerly over the Arabian Sea-Bay of Bengal region. This is due to the dominance of the L-mode flow over the annual mean flow. The reverse is true at the mid-latitude North Pacific, where the consolidated winds are westerly due to a greater contribution of the annual mean westerly jet. The most important indication in Fig. 11b is that the southwesterlies along the east coast of China, which are caused by the continental-scale heat low, serve as a bridge (or duct) that connects the monsoonal westerlies of tropical origin with the westerly jet of midlatitude origin. 
It is possible that the Baiu onset near Japan occurs as a part of the Rossby wave dispersion of Smode perturbations occurring within the sheared basic flow. The low-level westerly duct appears to facilitate time-clustering and partially spaceoverlapping development of S-mode disturbances. As seen in Figs. 11c and 11d, the S-mode disturbances including $C_{1}(s)$ and $A_{1}(s)$ cells are well organized in and around the westerly duct extending from South China Sea to the extratropical central North Pacific. This feature is similar to what is commonly known as a Rossby wave dispersion via the westerly duct. Actually, Kawamura et al. (1996) showed that convection-induced intraseasonal disturbances in the vicinity of the Philippines have a barotropic component through the interaction between the mean monsoon flow and disturbances, and the barotropic component effectively serves as an origin of the barotropic Rossby wave dispersion. If the seasonal phase lock of convection-induced disturbances around the Philippines is prominent, geographically fixed extratropical wavetrains are expected to occur frequently on particular calender dates, since the westerly duct is also geographically fixed by the seasonal evolution of L-mode. This mechanism seems to reasonably explain why the S-mode onset anticyclone is organized just to the northeast of the onset cyclone of convective origin. Furthermore, Tsuyuki and Kurihara (1989) postulated a possibility that stationary Rossby waves propagating poleward from the subtropics excite geographically fixed barotropic unstable modes in the extratropics. Their proposed idea may also be responsible for the formation of S-mode wavetrain structures. Kawamura et al. (1996) also postulated that in situ barotropic instability is likely to be triggered by a Rossby-wave dispersion emanating out of a localized convection just east of the Philippines.

The presence of horizontally sheared basic flow is expected to be prerequisite for in situ barotropic development of S-mode disturbances. Actually, the convection-induced $C_{1}(s)$ cell became most intense in the cyclonic shear zone inside the heat low at Pentad 35, but considerably weakened by Pentad 37 as it moved northward away from the westerly duct (not shown). Conversely, the $A_{1}(s)$ cell, which was generated just to the east of $C_{1}(s)$ around Pentad 35 , moved west-northwestward and became a very intense anticyclone as it intruded into the anticyclonic shear zone of the westerly duct. The consolidated effect of intensified $C_{1}(s)$ and $A_{1}(s)$ cells is to make the Baiu onset so quick in a climatological sense. Thus, an importance of the in situ barotropic interaction between S- and L-mode upon the Baiu onset may be implied.

We emphasize that the role of L-mode is to consolidate the westerly duct and to set a stage for activities of S-mode disturbances. The $C_{1}(s)$ and
$A_{1}(s)$ are the most influential S-type disturbances that make the Baiu onset so dramatic. For brevity, we will hereafter call them "onset cyclone" and "onset anticyclone," respectively. The onset anticyclone $A_{1}(s)$ stays active until Pentad 41 and exerts a crucial influence on the Baiu withdrawal.

\section{Baiu withdrawal}

\subsection{Contribution of L-mode to the Baiu withdrawal}

Evolution of L-mode before, during and after the Baiu withdrawal will be investigated by using the $z(l)$ and $[u(l), v(l)]$ maps at every four pentads from Pentad 37 to 45, as shown in Figs. 12a to 12f, respectively. In the vicinity of Japan, the L-mode lower tropospheric trough, which has persisted throughout the Baiu season (see, for example, Fig. 5c), tends to weaken and dissipate before the Baiu withdrawal (see Fig. 12a). At almost the same time, the locally independent L-mode anticyclonic cell over the Sea of Okhotsk loses its identity. Judging from changes in the $z(l)$ configuration, the Asian heat low appears to be deepest sometime between Pentad 37 and 41. Actually, $z(l)$ becomes minimum (less than $-60 \mathrm{~m})$ to the leeward of the northeastern Tibetan Plateau at Pentad 40 (figure not shown). After Pentad 40 (mid-July), the L-mode Asian heat low begins to weaken in close association with land-surface cooling. While weakening, the northeastern periphery of the L-mode heat low exhibits a tendency to move southward as if it is pushed by the westwardextending L-mode Pacific ridge. By contrast, the L-mode Pacific High still develops northward and reaches its peak around Pentad 43. The L-mode appears to rotate counterclockwise.

Associated with the development of another Lmode lower tropospheric trough are widespread southerly flows over the tropical Pacific all the way from $120^{\circ}$ to $170^{\circ} \mathrm{E}$ along about $25^{\circ} \mathrm{N}$, congruous with what we have already found in Fig. 7. Also note in Figs. 12b, 12d, and $12 \mathrm{f}$ that the enhanced heat trough, which will be hereafter signified as the "L-mode WNPM trough," seems to accelerate the cross-equatorial southerly flows over the maritime continent. These cross-equatorial southerlies, which represent the low-level branch of local Hadley circulations, converge into the L-mode WNPM trough after accelerating the southwesterly $[u(l), v(l)]$ flows to its south. This may imply that the L-mode WNPM trough is further reinforced by the local Hadley circulation. Through these interacting processes, WNPM becomes most active at Pentad 46 (e.g., Tanaka, 1992; Murakami and Matsumoto, 1994; Wang and $\mathrm{Xu}, 1997)$, i.e., about one month later than the Baiu withdrawal.

Figure 13 shows changes in $1000 \mathrm{hPa} T(l)$ from Pentad 37 to 47 . We have deliberately chosen such a long pentad difference to show up the changes in near-surface temperature in a conspicuous man- 


\section{a}
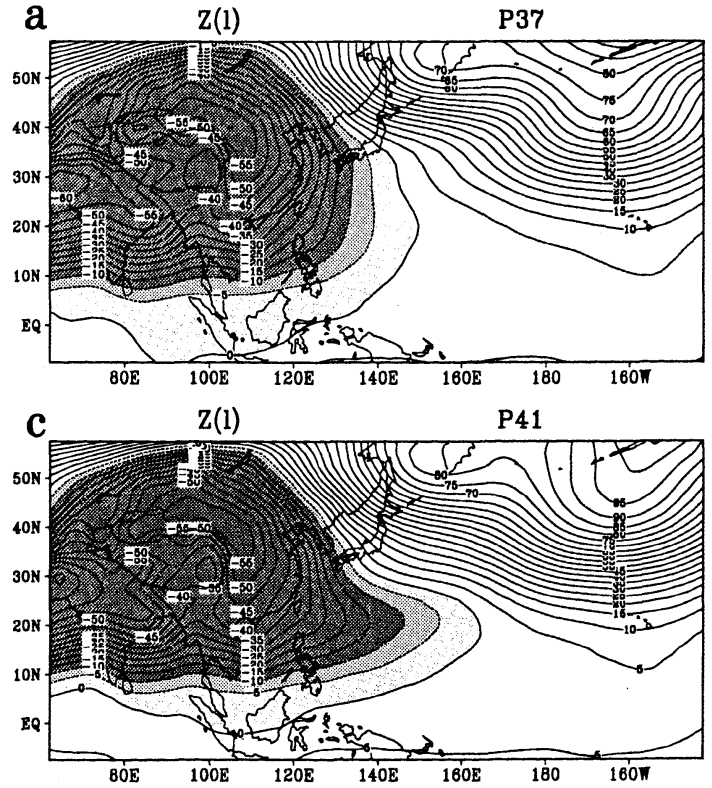

$\mathrm{Z}(1)$

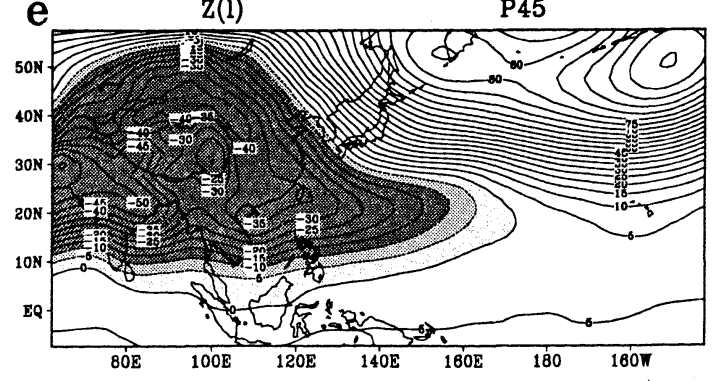

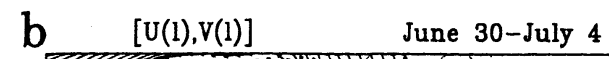
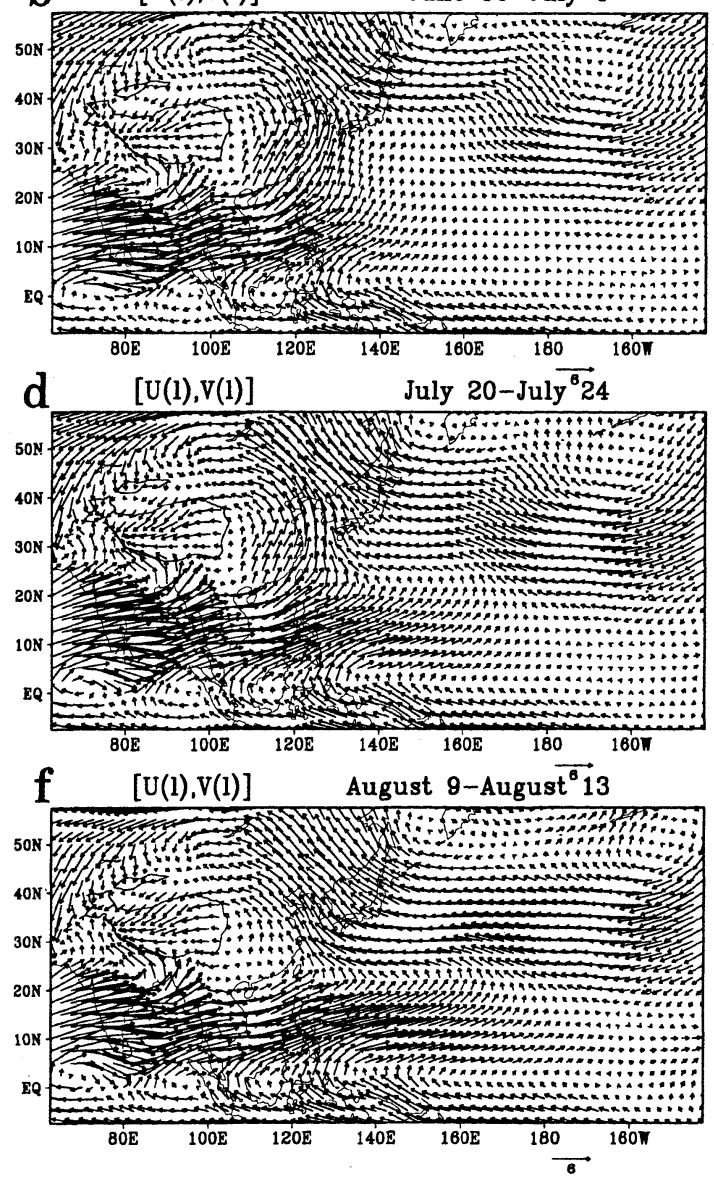

Fig. 12. Spatial patterns of $850 \mathrm{hPa}$ geoptential height $z(l)$ at Pentad 37 (a), Pentad 41 (c) and Pentad 45 (e). Contour interval is $5 \mathrm{~m}$, and shading indicates negative values. Spatial patterns of $850 \mathrm{hPa}$ wind $[u(l), v(l)]$ at Pentad $37(\mathrm{~b})$, Pentad 41 (d) and Pentad $45(\mathrm{f})$. Unit is $6 \mathrm{~m} \mathrm{~s}^{-1}$.

ner. As expected, $\Delta 1000 \mathrm{hPa} T(l)$ is negative over the majority of the Asian continent, which reflects the cooling-off of near-surface temperature due to a low heat capacity of the continent. Conversely, $\Delta 1000 \mathrm{hPa} T(l)$ is positive over the North Pacific region, suggesting that the near-surface temperature is still increasing up to Pentad 47 (August 19-23) due to a large heat capacity of the ocean. A remarkable band of high $\Delta 1000 \mathrm{hPa} T(l)$ in excess of $3^{\circ} \mathrm{C}$ stretches zonally from northern Japan to the central North Pacific along about $40^{\circ} \mathrm{N}$, reflecting an increase in solar radiation under high $T_{B B}$ areas.

An inspection of Fig. 13 also shows that the northsouth gradient of $\Delta 1000 \mathrm{hPa} T(l)$ between the equator and $30^{\circ} \mathrm{N}$ is directed poleward over Southeast Asia. Consequently, it is only natural that SEAM tends to dissipate from Pentad 37 to 47 . Yet WNPM still continues intensifying during the same period. One may argue that higher SST activates convection and then leads to maturing WNPM. This may be true, but $\Delta 1000 \mathrm{hPa} T(l)$ is only about $0.5^{\circ} \mathrm{C}$ or less, and even slightly negative over the western WNPM domain $\left(0^{\circ}-20^{\circ} \mathrm{N}, 120^{\circ}-140^{\circ} \mathrm{E}\right)$. It does not

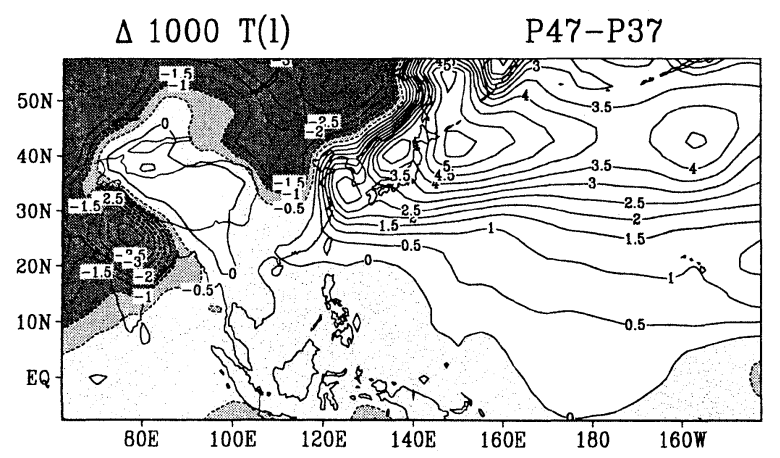

Fig. 13. Difference in $1000 \mathrm{hPa}$ temperature $T(l)$ between Pentad 37 and 47. Contour interval is $0.5 \mathrm{~K}$, and shading indicates negative values.

seem that the higher SST alone is capable of development of the planetary-scale monsoon system. We emphasize here that the decrease in the east-west thermal contrast between East Asia and the western North Pacific brings about the dissipation of Lmode anticyclonic circulations over the WNPM do- 

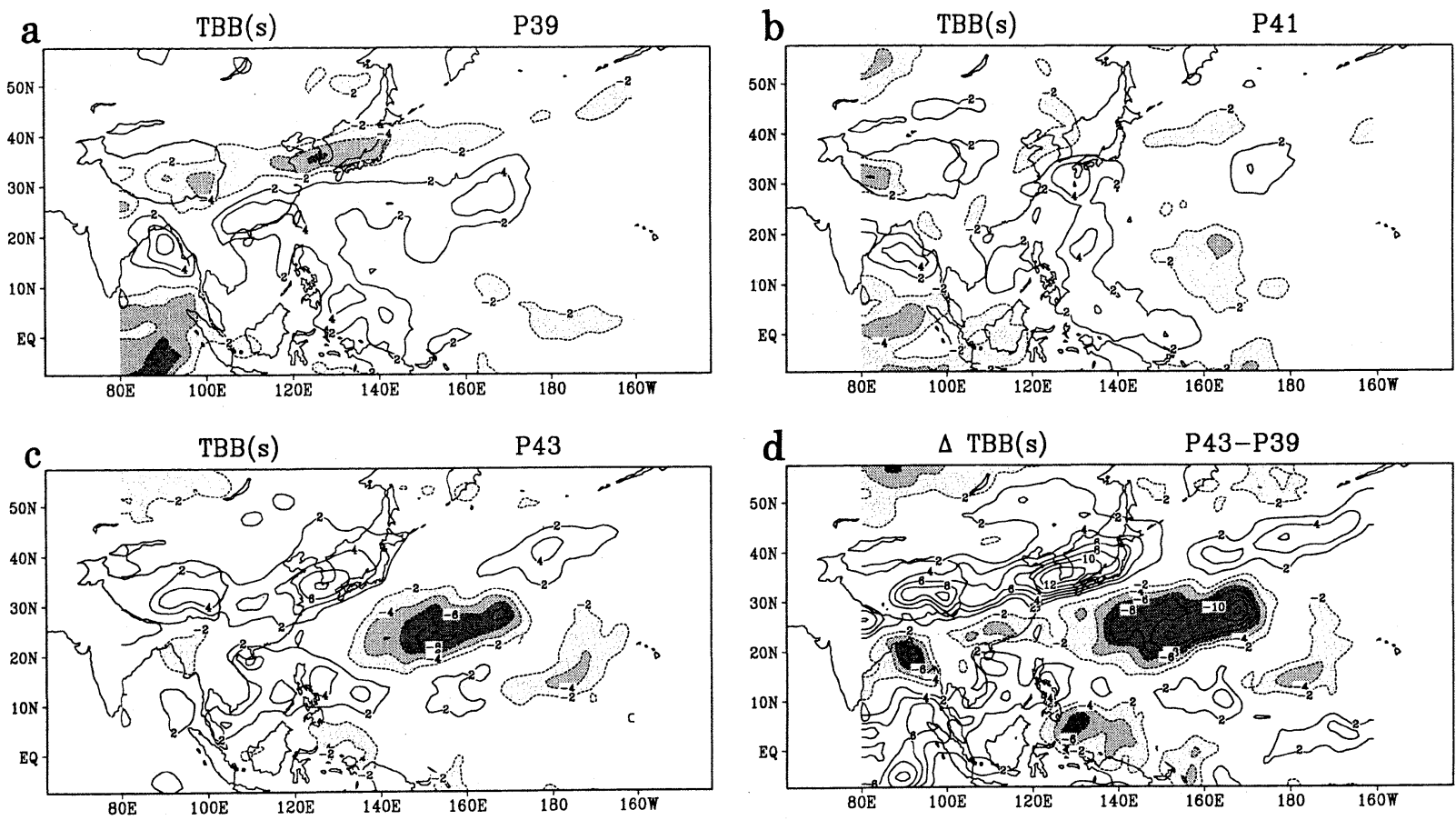

Fig. 14. Spatial patterns of $T_{B B}(s)$ at Pentad 39 (a), Pentad 41 (b) and Pentad 43 (c). Contour interval is $2 \mathrm{~K}$, and shading indicates negative values. (d) Difference in $T_{B B}(s)$ between Pentad 39 and 43.

main, eventually favoring intense convection in the warm pool region of the western Pacific. Once the planetary-scale monsoon circulation is established, widespread convection occurs throughout the monsoon domain.

\subsection{Contribution of $S$-mode to the Baiu withdrawal}

The $T_{B B}(\mathrm{~s})$ maps at every two pentads from Pentad 39 to 43 , together with the $\Delta T_{B B}(s)$ field, are shown in Figs. 14a to 14d, respectively. These are to be compared with the corresponding S-mode wind patterns as shown in Figs. 15a to 15d. First of all, the $A_{2}(s)$ anticyclone in Fig. 15a is a newly born cell developed just prior to Pentad 39 , whereas $A_{1}(s)$ was generated many pentads earlier, even before Pentad 35, and served as a Baiu onset anticyclone (see Fig. 11d). At Pentad 39, sandwiched between the $A_{1}(s)$ cell and $C_{2}(s)$ cell are strong westerly to southwesterly $[u(s), v(s)]$ winds (Fig. 15a) and associated convection (Fig. 14a), congruous with continued Baiu-type wet weather. By Pentad 41, the $A_{1}(s)$ anticyclone prevails around Japan and suppresses convection. As such, the $A_{1}(s)$ cell is the one that causes the Baiu to withdraw from Japan. In this respect, we now change its name from the "onset" to "withdrawal" anticyclone. Although negative $T_{B B}(s)$ areas were already routed from Japan, $C_{2}(s)$ is still responsible for relatively weak convection over northern Korea and off the east coast of Hokkaido at Pentad 41 (see Fig. 14b). A rain-belt is thus maintained in the vicinity of northern China, as exemplified in Matsumoto (1985). Of particular interest is that, at the same time with the Baiu withdrawal from Japan, a new cyclonic cell $C_{3}(s)$ is generated over the WNPM domain (Fig. 15b), accompanied by scattered weak convection (Fig. 14b). Two pentads later by Pentad 43, WNPM matures due to rapid intensification of the $C_{3}(s)$ cyclone in association with much intense convection. The development of convection-induced $C_{3}(s)$, which is related to the northwestward migration of $A_{1}(s)$ from Pentad 39 to 43 , is also responsible for the Baiu withdrawal, especially over Korea and the northeastern part of Japan. It should be noted that the withdrawal of Baiu is characterized by the dominance of S-mode disturbances as well as the Baiu onset.

\section{Counterclockwise progression of $z(l)$} anomalies during boreal summer

In Section $2, z(l)$ was defined as an anomaly relative to the annual mean. In Figs. 12a, 12c and 12e, one notes a distinct dipole configuration in $850 \mathrm{hPa}$ $z(l)$ with a negative (cyclonic) anomaly over East Asia while a positive (anticyclonic) anomaly exists over the western North Pacific. This dipole is thermally regulated by a temperature contrast between continent and ocean. Thus, the continental heat low (anomaly) remains centered over northern China throughout summer (see also Figs. 5a, 5c and 5e). Likewise, the L-mode anticyclone (anomaly) also persists near the Kamchatka-Aleutian region during 

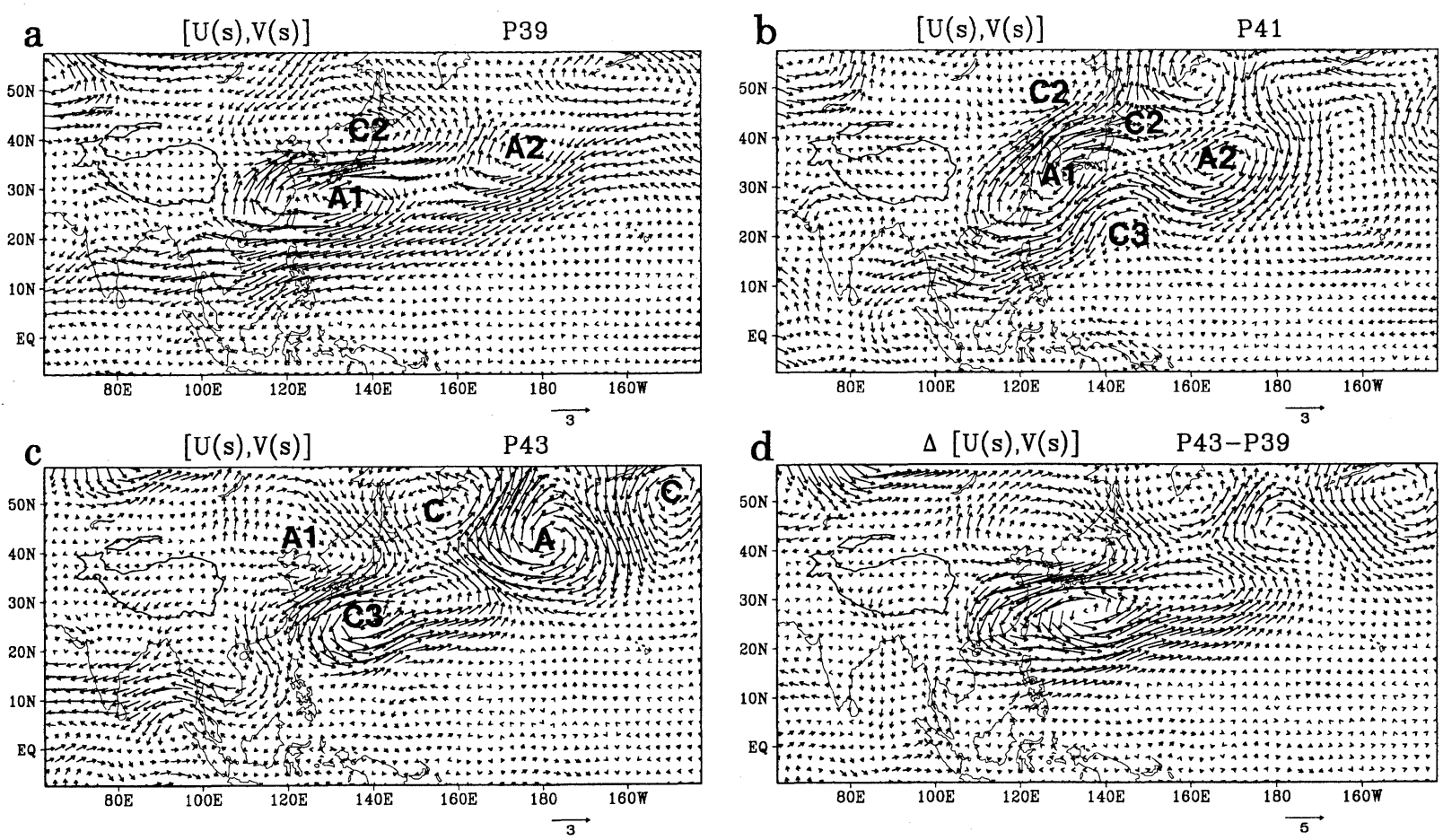

Fig. 15. As in Fig. 14, but for $850 \mathrm{hPa}$ wind $[u(s), v(s)]$. Unit is $3 \mathrm{~m} \mathrm{~s}^{-1}$, but for $5 \mathrm{~m} \mathrm{~s}^{-1}$ in (d). The letters $C$ and $A$ denote S-mode cyclonic and anticyclonic circulation cells, respectively.

the whole summer. Generally speaking, convections at any locality are activated (depressed) to above (below) normal during the cyclonic (anticyclonic) phase of $z(l)$ anomalies. It is, therefore, important to determine the phase (pentad) at which $z(l)$ becomes minimum (or maximum) at every grid point over the entire East Asia-North Pacific domain. The minimum (or maximum) $z(l)$ phase thus determined differs substantially from one geographical location to another, and tends to exhibit a counterclockwise progression. It is this counterclockwise propagating $z(l)$ phase that regulates local convective activities over the East Asia-western North Pacific domain. On a "trial and error" basis, it turns out that the counterclockwise $z(l)$ phase shift is most clearly defined over the domain enclosed by $110^{\circ} \mathrm{E}$ (west), $20^{\circ} \mathrm{N}$ (south), $180^{\circ} \mathrm{E}$ (east) and $40^{\circ} \mathrm{N}$ (north), respectively. Figure 16 plots $850 \mathrm{hPa} z(l)$ along these selected boundaries during the boreal summer of May to October.

The heavy full line in Fig. 16a traces the phase of a minimum $z(l)$ along $110^{\circ} \mathrm{E}$. More specifically, the minimum $z(l)$ phase at $\left(40^{\circ} \mathrm{N}, 110^{\circ} \mathrm{E}\right)$ occurs on Pentad 38 (July 5-9) with a $z(l)$ value of $-60 \mathrm{~m}$, while the minimum $z(l)$ phase at $\left(20^{\circ} \mathrm{N}, 110^{\circ} \mathrm{E}\right)$ is encountered about three pentads after at Pentad 41 (July 20-24) with a $z(l)$ value of $-43 \mathrm{~m}$. Therefore, the peak summer phase of minimum $z(l)$ is systematically displaced southward across China with an average phase speed of $-1.3 \mathrm{~m} \mathrm{~s}^{-1}$. As mentioned earlier in Figs. 12a and 12c, the continental heat low itself remains centered near $\left(40^{\circ} \mathrm{N}, 105^{\circ} \mathrm{E}\right)$ between Pentad 38 and 41.

Similarly, the heavy full line in Fig. 16b traces the phase of a minimum (cyclonic) $z(l)$ along $20^{\circ} \mathrm{N}$. Evidently, the phase progression is eastward (counterclockwise) with an approximate speed of $+1.2 \mathrm{~m} \mathrm{~s}^{-1}$. At Pentad 46 (August 14-18), the major part of WNPM from $125^{\circ}$ to about $150^{\circ} \mathrm{E}$ experiences the minimum $z(l)$ phase, reflecting the mature phase of WNPM convective activities. This minimum $z(l)$ phase is brought about by an eastward penetration of the continental heat low into the tropical western Pacific, as substantiated in Figs. $12 \mathrm{c}$ and $12 \mathrm{e}$. The amplitude of $z(l)$ anomalies along $20^{\circ} \mathrm{N}$ monotonically decreases as one approaches eastward to the dateline (see Fig. 16b). Undoubtedly, this is due to weakening of thermal forcing over the open ocean. Although very weak, cyclonic $z(l)$ anomalies also occur near $\left(20^{\circ}-27^{\circ} \mathrm{N}, 180^{\circ} \mathrm{E}\right)$ at Pentad 55 (September 28-October 2) in Fig. 16c. Hence, Pentad 55 corresponds to the peak summer phase over the equatorial central Pacific, which is about three months lagging behind the peak summer phase over northern China $\left(40^{\circ} \mathrm{N}, 110^{\circ} \mathrm{E}\right)$. A phase difference between continent and ocean depends sensitively on longitude and latitude, ranging from less than one month to as long as three months. Figure 16a also shows commencement of the winter phase over northern China as early as the beginning 

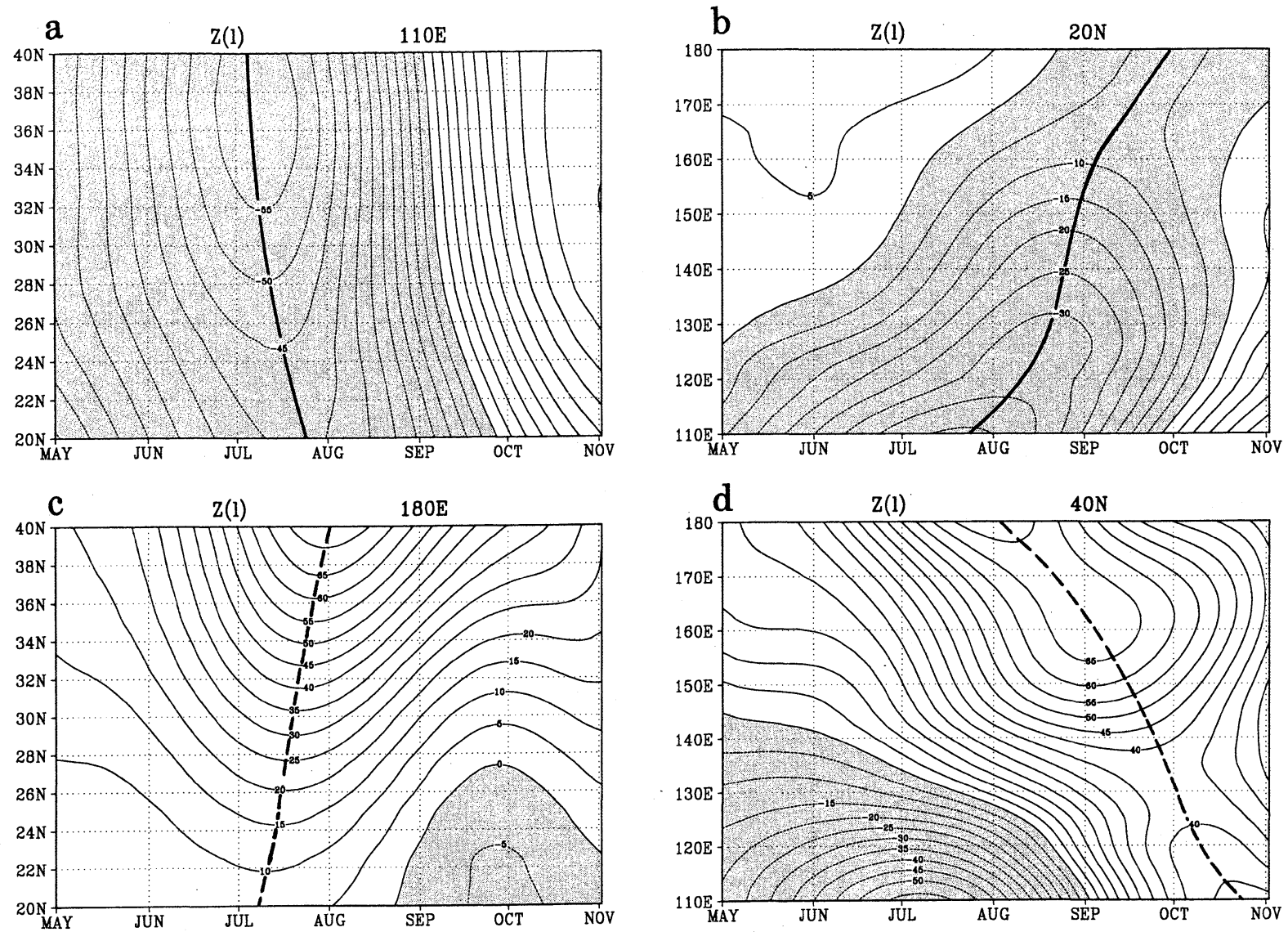

Fig. 16. (a) Time-latitude section of $850 \mathrm{hPa}$ geopotential height $z(s)$ at $110^{\circ} \mathrm{E}$. Contour interval is $5 \mathrm{~m}$, and shading denotes nigative values. (b) As in (a) but for time-longitude section at $20^{\circ} \mathrm{N}$. (c) As in (a) but for $180^{\circ} \mathrm{E}$. (d) As in (a) but for time-longitude section at $40^{\circ} \mathrm{N}$. The heavy solid and dashed lines denote the L-mode trough and ridge, respectively.

of September, as confirmed by changes from negative to positive $z(l)$ at $\left(40^{\circ} \mathrm{N}, 110^{\circ} \mathrm{E}\right)$. At this location, $z(l)$ becomes a maximum in excess of $+40 \mathrm{~m}$ by Pentad 59 (October 18-22), as shown in Fig. 16d.

Let us next trace the summertime maximum (anticyclonic) $z(l)$ phase along $180^{\circ} \mathrm{E}$ (Fig. 16c) and $40^{\circ} \mathrm{N}$ (Fig. 16d), respectively. It should be noted here that the heavy dashed lines in Figs. 16c and $16 \mathrm{~d}$ do not indicate an actual displacement of the summertime Pacific High (anomaly). An inspection of Fig. 16c indicates that the peak summertime anticyclonic $z(l)$ phase at $\left(20^{\circ} \mathrm{N}, 180^{\circ} \mathrm{E}\right)$ occurs around Pentad 38 (July 5-9). This is followed by a regular northward progression of the peak summer-time anticyclonic $z(l)$ phase from $20^{\circ}$ to $40^{\circ} \mathrm{N}$ along $180^{\circ} \mathrm{E}$, an approximate phase speed being $+0.9 \mathrm{~m} \mathrm{~s}^{-1}$. The counterclockwise phase progression is then completed by a westward shift $\left(-0.9 \mathrm{~m} \mathrm{~s}^{-1}\right)$ of the peak summertime anticyclonic $z(l)$ phase from $180^{\circ}$ to $110^{\circ} \mathrm{E}$ along $40^{\circ} \mathrm{N}$ (Fig. 16d). This westward migration of maximum $z(l)$ phase is directly, or indirectly, related to the westward extension of the Pacific ridge system over to Japan and beyond (see Figs. 12a, 12c and 12e). Associated with the westward progression of anticyclonic $z(l)$ anomalies is the termination of convective activities near Japan by Pentad 41 (July 20-24). The Baiu withdrawal occurs more than five pentads prior to the mature phase of WNPM.

During early summer, $z(l)$ anomalies behave differently from those in mid- to late-summer. More specifically, the counterclockwise progression of $z(l)$ anomalies tends to occur over a much higher latitude region of East Asia and the North Pacific. This statement can be justified by an inspection of Figs. $5 \mathrm{a}, 5 \mathrm{c}$ and 5e. An anticyclonic $z(l)$ cell, located off the east coast of the Kamchatka Peninsula at Pentad 27 , gradually drifts westward with its western edge covering the vastness of eastern Siberia by Pentad 35. Further south over Japan is contrasted with an eastward extension of the continental heat low between Pentad 27 and 35. At Pentad 31 (Baiu onset phase), the $z(l)$ anomaly exhibits a feature similar to that of a "blocking" with a deep east-west extended trough near Japan as against a substantially strong anticyclonic cell over Kamchatka.

In this section, evidence has been provided that 

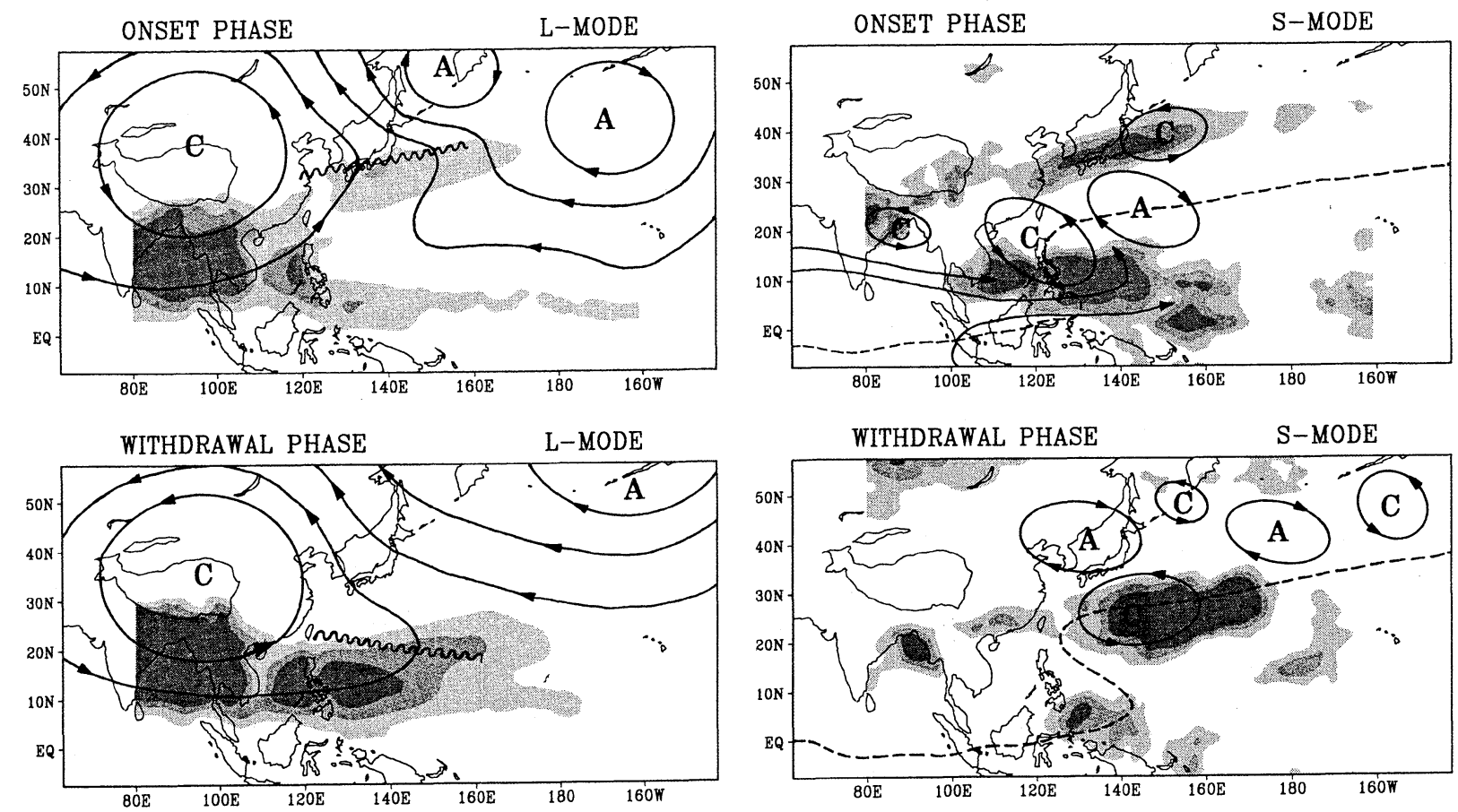

Fig. 17. Schematic diagrams of lower tropospheric L-mode flow and S-mode disturbances prevailing at the Baiu onset (mid-June) and withdrawal (late July) phases. The letters $C$ and $A$ denote L-mode (or S-mode) cyclonic and anticyclonic circulation cells, respectively. Shading indicates intense convection associated with the two modes. The wavy lines denote the L-mode lower tropospheric trough around Japan seen at the onset phase, and the L-mode WNPM trough at the withdrawal phase. The dashed lines denote the border between the climatological low-level westerlies and easterlies.

the L-mode, which follows the seasonal change in solar radiation, strongly regulates the climatological phase shift of convective activities over the Baiu domain. The L-mode is also the major regulator for the dry-to-wet phase shift over the WNPM region. As emphasized in Sections 3 and 4, another important effect of L-mode is to control S-mode activities. Finally, the consolidated contribution of L- and Smode is to make such local climatological events as the onset and withdrawal of Baiu and WNPM so rapid and dramatic.

\section{Concluding remarks and discussion}

In this study much of the needed documentation of the Baiu onset and withdrawal has been archived by partitioning the climatological pentad mean data into L- and S-components. The L-mode defines a slowly evolving annual cycle expressed by the sum of one, one half and one third yearly sinusoids, while the S-mode signifies a rapidly varying annual cycle obtained by summing up the remaining transient sinusoids.

The seasonal march of solar radiation strongly influences the evolution of the L-mode during boreal summer. There exists a significant phase difference in the L-mode response from one latitude to another between different longitudes of the Asian continent and the western North Pacific. Some of the major results are schematically summarized in Fig. 17. At the Baiu onset phase (mid-June), the continentalscale heat low becomes well established and dominates over almost all of East Asia. Associated with this is the enhancement of SEAM, as suggested by intense convection over the regions from the Bay of Bengal to the South China Sea (Fig. 17a). An Lmode anticyclone prevailing over the North Pacific implies the seasonal weakening of the Aleutian Low and the seasonal northward development of the Pacific High. Another locally independent L-mode anticyclonic cell in the vicinity of the Sea of Okhotsk, which corresponds to the development of the "climatological" Okhotsk High, enhances L-mode easterlies from the Aleutian islands through northern Japan. The L-mode easterlies merge with southwesterlies along the east coast of China, hence generating a pronounced cyclonic shear zone just around Japan accompanied by low-level moisture convergence. This L-mode lower tropospheric trough, intrinsically associated with the east-west temperature gradient between the Asian continent and the western North Pacific Ocean, plays a vital role in the formation of the Baiu system as a background field.

The L-mode southwesterly flow along the south- 
eastern periphery of the Asian continental heat low acts as bridge between the SEAM westerlies and mid-latitude westerlies dominating over the North Pacific, which produces a low-level westerly duct extending from the South China Sea to the central North Pacific. In the vicinity of the westerly duct, S-mode disturbances tend to be generated and enhanced. As shown in Fig. 17b, as soon as the S-mode onset cyclone of convective origin is established over the South China Sea, the S-mode onset anticyclone is organized to the northeast of the onset cyclone. These onset vortexes cause the northward advection of warm and moist air from the tropics to southern Japan. Another S-mode cyclonic cell located east of northern Japan, which transports cold and dry air from the Sea of Okhotsk to northern Japan, plays an influential role in producing a strong meridional gradient in both temperature and moisture fields across Japan. These features imply that the S-mode disturbances prevailing along the westerly duct contribute a great deal to the occurrence of the Baiu onset.

At the withdrawal phase (late July), the Asian continental heat low begins to decay in relation to surface cooling of the continent, but the L-mode Pacific High still develops northward and reaches its peak around Pentad 43. As the east-west thermal contrast between the ocean and continent decreases, the L-mode lower tropospheric trough around Japan dissipates, while the L-mode WNPM trough dominates in the warm pool region of the western Pacific (see Fig. 17c). The establishment of the L-mode WNPM trough makes it possible to trigger S-mode convective perturbations over the subtropical western Pacific, such as the S-mode withdrawal cyclone south of Japan. A couple of S-mode vortexes amplified in and around a low-level westerly duct; i.e., the withdrawal anticyclone just over Japan and the withdrawal convective vortex, are crucially responsible for rapid withdrawal of Baiu (Fig. 17d).

As can be seen in these two phases of Baiu, the S-mode disturbances over the western North Pacific region are strongly regulated by the seasonal evolution of L-mode circulations in association with continent-ocean thermal contrast. Very interestingly, the S-mode onset cyclone and onset anticyclone are amplified in L-mode cyclonic and anticyclonic shear zones, respectively. Another S-mode cyclonic cell just east of northern Japan seen at the onset phase is also enhanced in a L-mode cyclonic shear zone. These S-mode perturbations could thus be enhanced via in situ barotropic interaction between the two modes. One weakness in this study is a mere qualitative description on the S-L barotropic interaction. To remedy this deficiency, our plan calls for an application of the enstrophy equation introduced by Kawamura et al. (1996). The S-L barotropic in- teraction is expressed by a correlation between vorticity fluxes due to S-mode perturbations and the gradient of absolute vorticity in the L-mode flow, as well as in the annual mean flow. Here, caution must be exercised when evaluating the correlation, such that products of any $\mathrm{S}$ and $\mathrm{L}$ variables become approximately zero by choosing an optimum span of time integration. As already stated in previous sections, it is also possible that the westerly duct served as a wave guide for the Rossby wave dispersion of the S-mode perturbations. Much work needs to be done before we completely understand these possible mechanisms.

No remarkable S-mode anticyclonic cells over the Sea of Okhotsk are intensified at the onset phase of Baiu. We do not have any evidence that the Okhotsk High contributes significantly to the occurrence of Baiu onset in terms of S-mode activities. However, the prominence of individual Okhotsk Highs is supposed to partially enhance the Baiu front system, especially over northern Japan. Actually, there is a case in which an S-mode anticyclonic cell is intensified to the west of the Sea of Okhotsk around Pentad 36 after the onset (not shown). It is thus inferred that around the onset phase, the Okhotsk High tends to develop more randomly than S-mode disturbances of convective origin over the subtropical western Pacific. An important question still remains unanswered. Why do the S-mode disturbances recur at the same place over the East Asia-western Pacific domain every year on the same calendar date? Our speculation is that the slowly evolving, planetary-scale L-mode is strongly regulated by the annual cycle of solar radiation, so that it excites regional-scale S-mode perturbations according to the calendar date. This speculation requires further clarification.

Japan experiences the second rainy season ("Syurin" in Japanese) around September. As already indicated in Fig. 1, $\zeta(l)$ in the vicinity of Japan becomes negative (anticyclonic) at the beginning of August and it continues until winter, which means the absence of L-mode lower tropospheric trough, such as the L-mode Baiu trough, during Syurin. This may be why the Syurin front system is not stationary as compared to the Baiu. The absence of L-mode trough during Syurin is primarily attributed to the dissipation of the Asian continental heat low due to land-surface cooling.

\section{Acknowledgments}

We are grateful to Dr. K. Kato, Dr. J. Matsumoto and two anonymous reviewers for their helpful comments, which led to an improved manuscript. This research was partially supported by the JACCS program of the Japan Science and Technology Agency. 


\section{Appendix}

\section{List of Symbols}

$\lambda$

$\varphi$

$a$

$u, v \quad$ Zonal and meridional winds

$z \quad$ Geopotential height

T Temperature

$q \quad$ Mixing ratio of water vapor

$\zeta \quad$ Relative vorticity

$D \quad$ Divergence

$D Q \quad$ Moisture flux convergence as defined in Eq. (3)

$T_{B B} \quad$ Infrared equivalent black body temperature measured by Japanese geostationary satellites

$\langle A\rangle \quad$ Climatological pentad mean $A$ averaged for $1985-93$

$A(0) \quad$ Climatological annual mean $\langle A\rangle$

$A(l) \quad$ Sum of the first three harmonics in the $\langle A\rangle$ time series

$A(s) \quad$ Sum of the higher-order harmonics in the $\langle A\rangle$ time series

$\triangle A \quad$ Difference in $A$ between Pentad $_{i+2}$ and Pentad $_{i-2}, i=33$ or 41

\section{List of Acronyms}

L-mode Slowly evolving climatological annual cycle with periods longer than 120 days

S-mode Rapidly varying climatological annual cycle with periods shorter than 90 days

ITCZ Intertropical convergence zone

Baiu Early summer rainy season near Japan $\left(30^{\circ}-40^{\circ} \mathrm{N}, 120^{\circ}-160^{\circ} \mathrm{E}\right)$

SEAM Summer monsoon over Southeast Asia $\left(5^{\circ}-20^{\circ} \mathrm{N}, 60^{\circ}-100^{\circ} \mathrm{E}\right)$

WNPM Summer monsoon over the western North Pacific $\left(5^{\circ}-20^{\circ} \mathrm{N}, 110^{\circ}-\right.$ $\left.160^{\circ} \mathrm{E}\right)$

\section{References}

Asakura, T., 1971: Transport and source of water vapor in the Northern Hemisphere and monsoon Asia. In Water Balance at Monsoon Asia, 27-51. University of Tokyo Press, Tokyo.

Flohn, H. and H. Oeckel, 1956: Water vapor flux during the summer rains over Japan and Korea. Geophys. Mag., 27, 527-532.

Huang, R.H. and W.J. Li, 1987: Influence of the heat source anomaly over the western tropical Pacific on the subtropical high over East Asia. Proc. International conference on the general circulation of East Asia, 40-51.

Kato, K., 1985: On the abrupt change in the structure of the Baiu front over the China continent in late May of 1979. J. Meteor. Soc. Japan, 63, 20-36.

Kato, K., 1987: Airmass transformation over the semiarid region around North China and abrupt change in the structure of the Baiu front in early summer. J. Meteor. Soc. Japan, 65, 737-750.

Kato, K., 1989: Seasonal transition of the lower-level circulation systems around the Baiu front in China in 1979 and its relation to the northern summer monsoon. J. Meteor. Soc. Japan, 67, 249-265.

Kato, K., 1995: Synoptic characteristics of the Okhotsk High associated with Yamase. Kishou Kenkyuu, 183, 67-90, in Japanese.

Kawamura, R., T. Murakami and B. Wang, 1996: Tropical and midlatitude 45-day perturbations over the western Pacific during the northern summer. J. Meteor. Soc. Japan, 74, 867-890.

Khromov, S.P., 1957: Die geographishe Verbreitung der Monsune. Petermanns Geogr. Mitt., 101, 234-237.

Kodama, Y.-M., 1993: Large-scale features of subtropical convergence zones (the Baiu frontal zone, the SPCZ and the SACZ). Part II: Conditions of the circulations for generating the STCZs. J. Meteor. Soc. Japan, 71, 581-610.

Kurashima, A., 1968: Studies on the winter and summer monsoon in East Asia based on dynamic concept. Geophys. Mag., 34, 145-235.

Kurihara, K. and T. Tsuyuki, 1987: Development of the barotropic high around Japan and its association with Rossby wave-like propagations over the North Pacific: analysis of August 1984. J. Meteor. Soc. Japan, 65, 237-246.

Matsumoto, J., 1985: Precipitation distribution and frontal zones over East Asia in the summer of 1979. Bull. Dept. Geogr. Univ. Tokyo, 17, 45-61.

Murakami, T., 1958: The sudden change of upper westerlies near the Tibetan Plateau at the beginning of summer season. J. Meteor. Soc. Japan, 36, 239-247.

Murakami, T., 1959: The general circulation and water vapor balance over the Far East during the rainy season. Geophys. Mag., 29, 131-171.

Murakami, T. and J. Matsumoto, 1994: Summer monsoon over the Asian continent and the western North Pacific. J. Meteor. Soc. Japan, 72, 719-745.

Nakazawa, T., 1992: Seasonal phase lock of intraseasonal variation during the Asian summer monsoon. J. Meteor. Soc. Japan, 70, 597-611. 
Ninomiya, K., 1978: Heavy rainfalls associated with frontal depression in Asian subtropical humid region. Part I. J. Meteor. Soc. Japan, 56, 253-266.

Ninomiya, K., 1980: Enhancement of Asian subtropical front due to thermodynamic effect of cumulus convections. J. Meteor. Soc. Japan, 58, 1-15.

Ninomiya, K. and H. Muraki, 1986: Large-scale circulations over East Asia during Baiu period of 1979. J. Meteor. Soc. Japan, 64, 409-429.

Ninomiya, K. and T. Murakami, 1987: The early summer rainy season (BAIU) over Japan. Reviews in Monsoon Meteorology, edited by T.N. Krishnamurti and C.-P. Chang, Oxford University Press.

Nitta, T., 1987: Convective activities in the tropical western Pacific and their impact on the Northern Hemisphere summer circulation. J. Meteor. Soc. Japan, 65, 373-390.

Sadler, J.C., M.A. Lander, A.M. Hori and L.K. Oda, 1987: Tropical Marine Climatic Atlas, Vol. 2., Pacific Ocean. UHMET 87-02, Department of Meteorology, University of Hawaii, Honolulu, HI.

Saito, N., 1966: A preliminary study of the summer monsoon of southern and eastern Asia. J. Meteor. Soc. Japan, 44, 49-59.
Tao, S.-Y. and L.-X. Chen, 1987: The East Asian summer monsoon. Reviews in Monsoon Meteorology, edited by T.N. Krishnamurti and C.-P. Chang, Oxford University Press, 60-90.

Tanaka, M., 1992: Intraseasonal oscillation and the onset and retreat dates of the summer monsoon over east, southeast Asia and the western Pacific region using GMS high cloud amount data. J. Meteor. Soc. Japan, 70, 613-629.

Tian, S.-F. and T. Yasunari, 1998: Climatological aspects and mechanism of spring persistent rains over central China. J. Meteor. Soc. Japan, 76, 57-71.

Tsuyuki, T. and K. Kurihara, 1989: Impact of convective activity in the western tropical Pacific on the East Asian summer circulation. J. Meteor. Soc. Japan, 67, 231-247.

Ueda, H., T. Yasunari and R. Kawamura, 1995: Abrupt seasonal change of large-scale convective activity over the western Pacific in the northern summer. J. Meteor. Soc. Japan, 73, 795-809.

Wang, B. and X. Xu, 1997: Northern Hemisphere summer monsoon singularities and climatological intraseasonal oscillation. J. Climate, 10, 1071-1085.

梅雨と東南アジア・西太平洋モンスーン

\author{
川村隆一 \\ (防災科学技術研究所) \\ 村上多喜雄 \\ (ハワイ大学気象学教室)
}

赤外輝度温度、850 hPa 高度、風、気温、比湿デー夕に調和解析を適用し、季節変化の長周期成分 (第 1 から第 3 調和関数までの和)を $\mathrm{L}$ モート、残りの調和関数で表現される短周期成分を $\mathrm{S}$ モドと定義した。

初夏の期間、L モードはカムチャッカ半島一オホーツク海上のリッジと、中国北部 (大陸の熱的低気圧の 中心) から日本、さらに東方へ延びるトラフのブロッキング型循環パターンを示す。オホーツク海上の局所

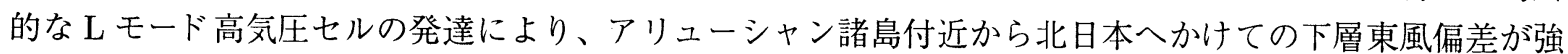
まる。この東風偏差と大陸の熱的低気圧の南東縁に沿った南西風偏差によって、日本付近で水蒸気収束を 伴う強い低気圧性シアーが形成される。初夏にみられる東アジアと西部北太平洋との間の東西温度勾配の 強化と関連した、L モード下層トラフの発達は梅雨システムの形成に必要である。

大陸スケールの熱的低気圧の発達に起因する、中国東岸に沿う L モード南西風は、モンスーン西風と中 緯度偏西風をつなぐブリッジとなり、結果として南シナ海から中部北太平洋へ延びる対流圈下層の西風ダ クトを生み出す。6月中旬の梅雨オンセット期には、対流起源の $\mathrm{S}$ モード onset cyclone が南シナ海上で発 達し、ほぼ同時に $\mathrm{S}$ モード onset anticyclone が onset cyclone の北東側に組織化される。下層西風ダクト 周辺の $\mathrm{S}$ モード擾乱の増幅が熱帯から日本南部へ、湿潤で温暖な空気の北向き移流をもたらしている。

7 月中旬までに、アジア大陸の熱的低気圧はそのピークに達し、関連して東南アジアの夏季モンスーン も最盛期が訪れる。7 月下旬の梅雨明け頃は、大陸の熱的低気圧は地表面冷却により衰退し始めるが、 $\mathrm{L}$ モード太平洋高気圧は依然として北へ発達し、8月初めに最盛期を迎える。海陸間の東西温度勾配の弱化 に伴い、日本付近の L モード下層トラフが消失し、一方では西太平洋モンスーン (WNPM) トラフが発達 する。また、梅雨オンセットと同様に梅雨明け時にも $\mathrm{S}$ モード擾乱の発達がみられる。 
このように、大陸-海洋の熱的コントラストに関係する、L モード循環の季節進行が、下層西風ダクト内

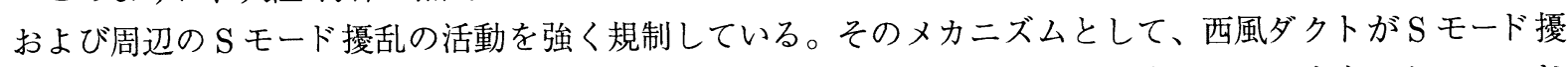
乱の順圧ロスビー波の分散に対する wave guide として働いている可能性や、水平シアーをもったLモード

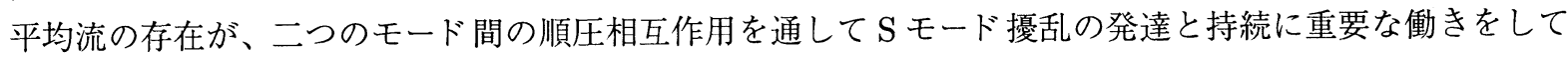

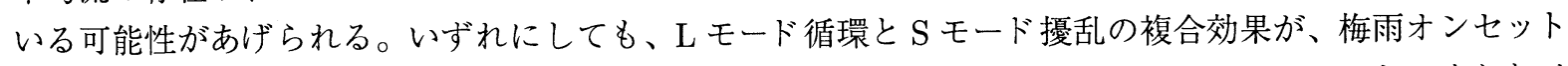
や梅雨明けのようなローカルな気候学的イベントを非常に急速かつ劇的な変化にしていることに変わりは ない。 